\title{
INDIGENOUS CUSTOMARY LAW AND INTERNATIONAL INTELLECTUAL PROPERTY: ASCERTAINING AN EFFECTIVE INDIGENOUS DEFINITION FOR MISAPPROPRIATION OF TRADITIONAL KNOWLEDGE
}

\author{
Nopera Dennis-McCarthy*
}

\begin{abstract}
The effective protection of indigenous traditional knowledge from misappropriation is a fundamental challenge faced by the intellectual property system. A substantial aspect of this challenge is how the intellectual property regime can practically utilise or incorporate indigenous customary law as a means of protection against misappropriation, when there is an inherent tension between the former and the latter. Any international legal instrument intended to protect against misappropriation of indigenous traditional knowledge will have to contend with this tension: a definition of misappropriation ought to encourage use of local indigenous customary law, but it also must be practically applicable within the confines of the intellectual property system. Consequently, this article considers the challenge in two parts. The first part requires ascertainment of a potential international legal definition of misappropriation that will uphold and maintain indigenous customary law, in the context of the World Intellectual Property Organization (WIPO) Intergovernmental Committee on Intellectual Property and Genetic Resources, Traditional Knowledge and Folklore (WIPO-IGC) draft articles. To ensure the definition effectively affirms indigenous customary law, it will be based on three key "approaches" to indigenous custom. The second part entails application of the definition to the domestic context, namely through the case studies of New Zealand and Australia, and a subsequent critique of the difficulties of application, to illustrate the challenge of incorporating indigenous customary law within the intellectual property
\end{abstract}

* He uri ahau nō Ngāti Whitikaupeka, Ngāti Tuwharetoa, Te Ātihaunui-a-Pāparangi. Originally submitted for the LLB (Honours) Degree, Faculty of Law, Victoria University of Wellington, 2019. The author would like to acknowledge Professor Susy Frankel for her supervision, and for her outstanding commitment to encouraging the academic study of indigenous intellectual property law amongst her students. 
system. This article concludes that the risks inherent in an aspirational definition of misappropriation which may have some challenges in application are outweighed by the potential of normalising and encouraging indigenous customary law as the foundational basis for truly effective protection of traditional knowledge against misappropriation.

\section{INTRODUCTION}

Indigenous traditional knowledge, in its many forms, has not always been afforded adequate protection under the laws and norms of the international intellectual property system. Many examples exist across the world of indigenous knowledge being misappropriated through the medium of intellectual property. ${ }^{1}$ Furthermore, the customary law of indigenous peoples is not necessarily easy to reconcile with the law of intellectual property. Nevertheless, the implementation of indigenous customary law may be the most effective means in which indigenous traditional knowledge can be protected from misappropriation. A critical theme underlying this article is that the current regime of intellectual property (the IP regime) is not sufficient to protect indigenous traditional knowledge from misappropriation because it does not reflect the needs, rights and obligations of indigenous peoples over their traditional knowledge, as illustrated effectively by Riley: ${ }^{2}$

While international and national regimes have extended some protections to ... indigenous peoples, in many respects the results have not corresponded to their needs. Although there has been some participation by indigenous peoples in the development of these laws, the result has, nevertheless, largely been the creation of top-down, international norms that have yet to take shape and that are rarely sufficiently multi-faceted to encompass the differences among indigenous groups.

Thus, utilising indigenous customary law to craft a definition of "misappropriation" in the context of intellectual property could have the dual effect of ensuring that indigenous traditional knowledge is well-protected, and that the rights of indigenous peoples (and their laws) are upheld.

A famous whakatauki, or proverb, in te ao Māori, comes from Te Kooti Arikirangi Te Turuki: ${ }^{3}$

1 For examples relating to New Zealand and Australia see Waitangi Tribunal Ko Aotearoa Ténei: A Report into Claims Concerning New Zealand Law and Policy Affecting Māori Culture and Identity - Te Taumata Tuatahi (Wai 262, 2011) [Ko Aotearoa Tēnei: Te Taumata Tuatahi]; and Terri Janke Indigenous Knowledge: Issues for protection and management - Discussion Paper (IP Australia and the Department of Industry, Innovation and Science, 2018).

2 Angela Riley "'Straight Stealing': Towards an Indigenous System of Cultural Property Protection" (2005) 80 WLR 69 at 86 (emphasis added). See also Intergovernmental Committee on Intellectual Property and Genetic Resources, Traditional Knowledge and Folklore Report of Indigenous Expert Workshop on Intellectual Property and Genetic Resources, Traditional Knowledge and Traditional Cultural Expressions WIPO/GRTKF/IC/28/INF/9 (29 January 2014).

3 Judith Binney Redemption Songs: A Life of Te Kooti Arikirangi Te Turuki (Bridget Williams Books, Wellington, 1995) at 490. 
Ko te waka hei hoehoenga mo koutou i muri i ahau, ko te Ture, mā te ture anō te Ture e āki.

The canoe for you to paddle after me is the Law, for only the Law can correct the Law.

Te Kooti's whakatauki is the foundation upon which this thesis will be developed. In this article, I will seek to expound the proposition that use of the "Law" (as in customary law) of indigenous peoples is the best way to correct the "Law" (as in the international law of intellectual property), to augment safeguards for traditional knowledge from misappropriation. There are two reasons which necessitate this discussion.

Firstly, despite increasing recognition of the rights of indigenous peoples in the international sphere, exemplified in treaties such as the United Nations Declaration on the Rights of Indigenous Peoples (UNDRIP) ${ }^{4}$ the protection of indigenous peoples' intellectual property through international law is far from adequate. ${ }^{5}$ There is no current international intellectual property instrument which protects traditional knowledge. ${ }^{6}$ A significant concern of indigenous peoples, given this lacuna, is the misappropriation of traditional knowledge through the IP regime. ${ }^{7}$ The Intergovernmental Committee on Intellectual Property and Genetic Resources, Traditional Knowledge and Folklore (WIPO-IGC) of the World Intellectual Property Organisation (WIPO) is currently in the process of drafting an international legal instrument which aims to protect indigenous traditional knowledge. ${ }^{8}$

Secondly, a significant point of contention in the current drafting of the instrument concerns the definition of "misappropriation". 9 The manner in which this term is defined will likely have a

4 Declaration on the Rights of Indigenous Peoples GA Res 61/295, A/RES/61/295 (2007) [UNDRIP].

5 Maui Solomon "An Indigenous Perspective on the WIPO IGC" in Daniel F Robinson, Ahmed Abdel-Latif and Pedro Roffe (eds) Protecting Traditional Knowledge: The WIPO Intergovernmental Committee on Intellectual Property and Genetic Resources, Traditional Knowledge and Folklore (Routledge, Abingdon (UK), 2017) 219 at 220.

6 Intergovernmental Committee on Intellectual Property and Genetic Resources, Traditional Knowledge and Folklore The Protection of Traditional Knowledge: Updated Draft Gap Analysis WIPO/GRTKF/IC/37/6 (20 July 2018) at 20.

7 World Intellectual Property Organization Intellectual Property Needs and Expectations of Traditional Knowledge Holders: WIPO Report on Fact-finding Missions on Intellectual Property and Traditional Knowledge (1998-1999) (April 2001) at 70 and 86; and Brendan Tobin The Role of Customary Law in Access and Benefit-Sharing and Traditional Knowledge Governance: Perspectives From Andean and Pacific Island Countries (World Intellectual Property Organization and United Nations University, 2013) at 7.

8 Intergovernmental Committee on Intellectual Property and Genetic Resources, Traditional Knowledge and Folklore The Protection of Traditional Knowledge: Draft Articles WIPO/GRTKF/IC/40 (June 2019).

9 IGC, above n 6, at 26-29; and Intergovernmental Committee on Intellectual Property and Genetic Resources, Traditional Knowledge and Folklore The Protection of Traditional Knowledge: Factual Extraction WIPO/GRTKF/IC/12/5(b) (18 February 2008). 
significant influence on the scope and effect of the instrument. ${ }^{10}$ Given the importance of this definition, the WIPO-IGC has acknowledged that it ought to incorporate, or at least recognise, indigenous customary law within it. ${ }^{11}$

The aim of this article is to analyse how this incorporation may occur. It consists of two major parts. First, how relevant approaches based on indigenous customary law might be incorporated into a definition of misappropriation to more effectively protect against it. Second, how this definition might apply in a national context, using case studies from New Zealand and Australia.

\section{BACKGROUND AND CONTEXT}

\section{A Defining Traditional Knowledge}

There is no single definition of "traditional knowledge" in international law. ${ }^{12}$ Under art 31 of UNDRIP, indigenous peoples have the right to maintain, control, protect and develop their cultural heritage, traditional knowledge and traditional cultural expressions, and the intellectual property concerning all of these. ${ }^{13}$ Indigenous peoples have also used the term, including the South American CAN Indigenous Group on Biodiversity, which defines traditional knowledge as: ${ }^{14}$

... all the ancestral wisdom and collective knowledge held by indigenous ... peoples ... based on age-old practice and the process of interaction between man and nature, and passed on from generation to generation, usually orally.

Notably, many indigenous groups do not utilise the term traditional knowledge, but instead focus on similar, localised concepts such as mātauranga Māori: a Māori worldview encompassing Māori traditional knowledge. ${ }^{15}$

10 Ruth L Okediji "A Tiered Approach to Rights in Traditional Knowledge" (2019) 58 Washburn LJ 271 at 272 273.

11 Intergovernmental Committee on Intellectual Property and Genetic Resources, Traditional Knowledge and Folklore Customary Law, Traditional Knowledge and Intellectual Property: An Outline of the Issues (2013) at 9; Rodrigo de la Cruz Regional Study in the Andean Countries: "Customary Law in the Protection of Traditional Knowledge" (World Intellectual Property Organization, November 2006) at 5; and Tobin, above n 7 , at 4 .

12 IGC, above n 6, at 21.

13 UNDRIP, above n 4, art 31.

14 Cruz, above n 11, at 22.

15 Ko Aotearoa Tēnei: Te Taumata Tuatahi, above n 1, at 6. 
Furthermore, WIPO has recognised, although setting out a definition in its latest version of the draft articles on traditional knowledge, ${ }^{16}$ that there are several difficulties with introducing a definition that is too limited. Firstly, traditional knowledge can arise in a broad range of forms. ${ }^{17}$ For example, it can be both "fixed" (in the intellectual property sense) in that it is visually or orally recorded or reproduced, ${ }^{18}$ and "unfixed" in that it is not recorded in any tangible form (such as oral histories or songs passed down intergenerationally). ${ }^{19}$ Secondly, traditional knowledge is not always limited to indigenous knowledge. ${ }^{20}$ However for the purposes of this article, traditional knowledge will be limited to knowledge of indigenous peoples. ${ }^{21}$

A further definition is a set of five attributes expressed by Okediji. These provide a useful description because they recognise the important cultural, collective and localised nature of traditional knowledge. These are: ${ }^{22}$

(1) an inter-generational system of institutions, norms, and processes that govern knowledge production;

(2) the knowledge is held collectively; (3) the knowledge is expressed in tangible and intangible forms, including specific manifestations in technical know-how, skills, works of authorship, and inventions; (4) the knowledge is governed by economic, spiritual, and cultural values; and (5) the knowledge is associated with a specific indigenous group ...

Importantly, the WIPO-IGC has specifically distinguished traditional knowledge from traditional cultural expression. The latter is concerned with the expression of traditional cultural practices or knowledge by indigenous peoples, such as through verbal, non-verbal, physical, tangible or nontangible forms. ${ }^{23}$ Conversely, the WIPO-IGC has placed greater focus on traditional knowledge as

16 IGC, above n 8, at 5, definition of "traditional knowledge": "knowledge originating from indigenous [peoples], local communities and/or [other beneficiaries] that may be dynamic and evolving and is the result of intellectual activity, experiences, spiritual means, or insights in or from a traditional context, which may be connected to land and environment, including know-how, skills, innovations, practices, teaching, or learning".

17 Intergovernmental Committee on Intellectual Property and Genetic Resources, Traditional Knowledge and Folklore List and Brief Technical Explanation of Various Forms in Which Traditional Knowledge May Be Found WIPO/GRTKF/IC/17/INF/9 (5 November 2010).

18 Peter K Yu "Cultural Relics, Intellectual Property, and Intangible Heritage" (2008) 81 Temp L Rev 433 at 461

19 IGC, above n 17, at [11]-[12].

20 WIPO above $\mathrm{n} 7$, at 9 .

21 For a definition of indigenous peoples in international law see International Labour Organisation " C169 Indigenous and Tribal Peoples Convention, 1989 (No 169)" (adopted 27 June 1989, entered into force 5 September 1991).

22 Okediji, above n 10, at 273.

23 IGC, above n 8, at 4 . 
the specific subject of rights and entitlements, with a more precise focus on the content and substance of knowledge. ${ }^{24}$

Finally, the issues with the definition of traditional knowledge as a whole should be noted. Drahos and Frankel depict these issues as the "[q]uicksands of [d]efinition". ${ }^{25}$ They recognise that the differing domestic and international legal instruments have contributed to the development of a plethora of definitions relating to traditional knowledge. ${ }^{26}$ However these legally based definitions do not necessarily emphasise the relational dynamics created by the possession of knowledge critical to indigenous peoples. ${ }^{27}$ Traditional knowledge is a broad term which often fails to capture the relationship of indigenous peoples to their knowledge, and obligations to maintain it for future generations. ${ }^{28}$ This is illustrated through the Māori concept of kaitiakitanga, which not only empowers Māori to protect their knowledge as a taonga (treasure), but also emphasises their obligations as kaitiaki or "guardians" over that knowledge as a fundamental aspect of their culture, identity and whakapapa (genealogy or kinship line). ${ }^{29}$ This article will show that the application of a recommended definition of misappropriation which upholds indigenous customary law would require a significant change from the status quo because that definition would require states to acknowledge effectively those relational dynamics inherent within indigenous traditional knowledge, and how they are affected by misappropriation. ${ }^{30}$

\section{B Defining Customary Law and Key Approaches}

\section{The inherent tension between indigenous customary law and property rights}

A central tenet of this article is that any effective definition of misappropriation must adopt a customary law-based approach. This is because of the constraints of the intellectual property system and the tensions that sometimes arise between that system and indigenous customary law. A useful starting point to explain these tensions is to identify the differing foundations of the two systems. In its Wai 262 report, the Waitangi Tribunal engages in a discussion of the purpose and history of

24 IGC, above n 6, at 20.

25 Peter Drahos and Susy Frankel "Indigenous Peoples' Innovation and Intellectual Property: The Issues" in Indigenous Peoples' Innovation: Intellectual Property Pathways to Development (ANU Press, Canberra, 2012) 1 at 9 .

26 At 9.

27 At 9

28 At 9 .

29 At 9. For a definition of taonga see Hirini Moko-Mead Tikanga Maori: Living by Māori Values (Huia Publishers, Wellington, 2016) at 73. For a definition of kaitiakitanga see Richard Benton, Alex Frame and Paul Meredith Te Mātāpunenga: A Compendium of References to the Concepts and Institutions of Māori Customary Law (Victoria University Press, Wellington, 2013) at 105.

30 Drahos and Frankel, above n 25, at 9. 
intellectual property rights. ${ }^{31}$ The Tribunal defines intellectual property as a classic western legal technique to express the interests of the creator, inventor, or owner in their creation - by vesting in them a right of property over that creation. ${ }^{32}$ Property rights are often expressed as a "bundle of rights" in that the person upon whom the rights are conferred has a number of enforceable rights against others, or against the world. ${ }^{33}$ Under this conception, property is characterised as insentient and subject to the "sole and despotic dominion of humankind".34

Importantly, this fundamental conception of "property rights" also applies to intellectual property. Those who have exclusive legal rights over intellectual property have the ability to benefit from its use or enforce their rights. ${ }^{35}$ These exclusive rights are balanced by limitations, such as the duration of exclusive use and subject matter (what can and cannot be protected). ${ }^{36}$ Furthermore, intellectual property rights are justified by incentives; patents are intended to encourage innovation by rewarding inventors with the right to exclusively exploit their inventions over a limited time, which in turn may benefit society. ${ }^{37}$ Intellectual property rights are characterised as a system conferring exclusive rights and privileges, justified by incentives and balanced by limitations and exceptions. ${ }^{38}$

Indigenous customary law is premised upon different conceptual foundations. It places greater emphasis on communal obligations, ${ }^{39}$ rather than individualised, exclusive rights. ${ }^{40}$ As noted by Daes, for indigenous peoples, property and traditional knowledge are based on a "bundle of

31 Ko Aotearoa Tēnei: Te Taumata Tuatahi, above n 1, at 31.

32 At 33 .

33 Denise R Johnson "Reflections on the Bundle of Rights" (2007) 32 Vt L Rev 247 at 253.

34 William Carey Jones (ed) Commentaries on the Laws of England by Sir William Blackstone (BancroftWhitney, San Francisco, 1915) at 707.

35 Ko Aotearoa Tēnei: Te Taumata Tuatahi, above n 1, at 33.

36 At 33

37 At 31. See also Alain Pottage and Brad Sherman Figures of Invention: A History of Modern Patent Law (Oxford University Press, Oxford, 2010).

38 Christoph B Graber and Jessica C Lai Intellectual Property: Law in Context (University of Lucerne, Working Paper No 2014/01, 2014) at 5.

39 Rebecca Tsosie "Land, Culture, and Community: Reflections on Native Sovereignty and Property in America" (2001) 34 Ind L Rev 1291 at 1306; and Rebecca Tsosie "Tribal Environmental Policy in an Era of SelfDetermination: The Role of Ethics, Economics, and Traditional Ecological Knowledge" (1996) 21 Vt L Rev 225 at $274-75$.

40 Waitangi Tribunal Whanganui River Report (Wai 167, 1999) at 35, 38 and 56-58; Waitangi Tribunal Te Whanganui-A-Orotu Report 1955 (Wai 55, 1995) at 201; Waitangi Tribunal Te Urewera Report Part V (Wai 894, 2014) at 30-38; and Ko Aotearoa Tēnei: Te Taumata Tuatahi, above n 1, at 67-68. 
relationships, rather than a bundle of economic rights". ${ }^{41}$ This is recognised in Wai 262 where the Tribunal discusses how "kaitiakitanga rights" are bestowed under tikanga Māori to a communal group because they have customary law obligations to the taonga that is either the knowledge itself, or the creation based upon that knowledge. ${ }^{42}$ Similarly in Australia, the courts have recognised in some copyright disputes that while the indigenous creators of the works may have exclusive, individual rights, they were bound by communal obligations to their clan to protect the cultural integrity of indigenous knowledge expressed in their works. ${ }^{43}$

\section{Defining indigenous customary law}

A framework which tried to cover the different principles, laws, and customs followed by different indigenous groups would fail to recognise that indigenous law is often localised to each indigenous group. ${ }^{44}$ WIPO has stressed that the role of international law is not to harmonise all principles of indigenous customary law into a single framework, but rather to create flexible mechanisms which ensure respect for different customary law regimes. ${ }^{45}$ Consequently, I posit that given the dynamic nature of indigenous customary law, a more effective method for applying it in the IP regime is to adhere to three key approaches when forming a definition for misappropriation:

(a) a localised approach

(b) a collective approach; and

(c) a holistic approach.

\section{A localised approach}

A localised approach to indigenous customary law would focus on the customs of the specific indigenous group which has been wronged. ${ }^{46}$ Article 12 of UNDRIP asserts that indigenous peoples have the right to manifest, practice, develop and teach their spiritual and religious traditions and

41 Erica-Irene Daes Study on the protection of the cultural and intellectual property of indigenous peoples (United Nations Commission on Human Rights, E/CN.4/Sub.2/1993/28, 28 July 1993) at [26].

42 Ko Aotearoa Tēnei: Te Taumata Tuatahi, above n 1, at 50.

43 Milpurrurru v Indofurn Pty Ltd (1994) 54 FCR 240 (FCA); and Bulun Bulun v R \& T Textiles Pty Ltd (1998) 86 FCR 244 (FCA). See also Mary Graham "Some Thoughts about the Philosophical Underpinnings of Aboriginal Worldviews" (2008) 45 AHR 181.

44 For an example of different laws and principles across indigenous groups see John Borrows "Indigenous Legal Traditions in Canada" (2006) 19 Washington University of Law \& Policy 167; Moko-Mead, above n 29; Benton, Frame and Meredith, above n 29; and Graham, above n 43.

45 Tobin, above $\mathrm{n} 7$, at 87.

46 Ad Hoc Open-Ended Inter-Sessional Working Group On Article 8(J) and Related Provisions of the Convention On Biological Diversity Report of the Expert Group Meeting of Local Community Representatives within the Context of Article $8(\mathrm{~J})$ and Related Provisions of the Convention on Biological Diversity UNEP/CBD/WG8J/7/8/Add.1 (4 September 2011) at 12. 
customs. Furthermore, arts 3 and 4 assert that indigenous peoples have the right to self-determination in matters relating to their own local and international affairs. Application of a localised approach when developing a definition for a concept such as misappropriation would be an effective means of upholding indigenous self-determination. ${ }^{47}$ Therefore, an act of misappropriation is not simply a breach of international law or even of sui generis domestic law, but a breach of an indigenous peoples' own law. ${ }^{48}$

The notion of locality and "local communities" has been a recurrent theme in the WIPO-IGC's work. ${ }^{49}$ For example, in a report detailing its fact-finding missions on traditional knowledge, WIPO acknowledged the importance of protecting traditional knowledge by the application of customary intellectual property law "on its own terms". ${ }^{50}$ A critical case study focused on a South Asian (Bangladesh, India and Sri Lanka) ritualised protection regime over traditional medicinal knowledge, whereby traditional healers utilised informal means, such as secrecy and rituals, to effectively protect, enforce and gain benefits from their knowledge. ${ }^{51}$ This case study exemplified the importance and usefulness of adopting a local indigenous customary regime to protect traditional knowledge, because it both acknowledges the expectations of indigenous peoples to have their customary norms

47 Intergovernmental Committee on Intellectual Property and Genetic Resources, Traditional Knowledge and Folklore Presentation Made by Ms Dalee Sambo Dorough (Indigenous Panel) WIPO/GRTKF/IC/28/ INDIGENOUS PANEL/MS DALEE SAMBO DOROUGH (7 July 2014) at 8.

48 For a specific local example see Intergovernmental Committee on Intellectual Property and Genetic Resources, Traditional Knowledge and Folklore WIPO Panel on Indigenous and Local Communities' Concerns and Experiences in Promoting, Sustaining and Safeguarding Their Traditional Knowledge, Traditional Cultural Expressions and Genetic Resources: Applying Practical Lessons of Community Experience WIPO/GRTKF/IC/13/INF/5(b) (13 October 2008).

49 For other examples of the participation of indigenous local communities in the IGC process see Intergovernmental Committee on Intellectual Property and Genetic Resources, Traditional Knowledge and Folklore Practical Workshop for Indigenous Peoples and Local Communities on IP and TK WIPO/GRTKF/IND/GE/13 (6 December 2013); World Intellectual Property Organization Participation of Indigenous and Local Communities; Establishment of a Voluntary Fund; Recommendation of the Intergovernmental Committee on Intellectual Property and Genetic Resources, Traditional Knowledge and Folklore WO/GA/32/6 (24 August 2005) at [annex]; and Intergovernmental Committee on Intellectual Property and Genetic Resources, Traditional Knowledge and Folklore Presentation Made By Mr Q'apaj Conde Choque (Indigenous Panel): Indigenous Peoples' and Local Communities' Expectations For The Protection of TK and Traditional Cultural Expressions WIPO/GRTKF/IC/35/PRESENTATION/3CONDE (28 March 2018).

50 WIPO, above n 7, at 57.

51 At 59 . 
recognised, ${ }^{52}$ and provides a localised method of dealing with misappropriation, acceptable to the indigenous community. 53

A useful example of the importance of this approach involved the protection of the traditional knowledge stemming from the ecosystems in the Mojanda Cajas Plateau in Ecuador, where the indigenous peoples sought protection mechanisms that recognised that the flora and fauna of the area was a part of Pacha Mama (in its simplest terms, Mother Earth). ${ }^{54}$ Similarly, several Pacific island states have developed a Regional Framework for the Protection of Traditional Knowledge, which provides that if not all traditional owners have been identified, or there is a dispute about ownership, the matter must be referred "to the persons concerned to be resolved according to customary law and practice". 55

\section{A collective approach}

A collective approach is concerned with upholding the collective or communal rights of indigenous peoples, which are often a significant element within indigenous customary law. They are referenced several times in UNDRIP, ${ }^{56}$ as well as the Convention on Biological Diversity (CBD). ${ }^{57}$ Adopted in 1992, the CBD reflects the global intent to create an international legal instrument for the sustainable use of biodiversity. ${ }^{58}$ Of particular importance is the CBD's additional Nagoya Protocol, which takes indigenous customary laws into consideration by introducing access and benefit-sharing obligations when traditional knowledge associated with genetic resources is utilised. ${ }^{59}$

Tobin also identifies a significant emphasis on collective rights, collective ownership and collective wellbeing across indigenous customs and social structures. ${ }^{60}$ Similarly, Coffey and Tsosie

52 At 58 .

53 At 63 .

54 Cruz, above n 11, at 31-32.

55 Secretariat of the Pacific Community, Pacific Islands Forum Secretariat and UNESCO Pacific Regional Office Regional Framework for the Protection of Traditional Knowledge and Expressions Of Culture (2002), s 18(1).

56 Articles 1,7(2) and 40.

57 Convention on Biological Diversity 1760 UNTS 79 (opened for signature 5 June 1992, entered into force 29 December 1993) [CBD].

58 At [preamble].

59 Nagoya Protocol on Access to Genetic Resources and the Fair and Equitable Sharing of Benefits Arising from their Utilization to the Convention on Biological Diversity UNEP/CBD/COP/DEC/X/1 (opened for signature 2 February 2011, entered into force 12 October 2014), at 12.

60 Brendan Tobin Indigenous Peoples, Customary Law and Human Rights: Why Living Law Matters (Routledge, Abingdon (UK), 2014) at 32. 
stress that indigenous "property" systems often revolve around principles of collective or communal ownership. ${ }^{61}$ Both Borrows and Tully have emphasised this in the First Nations context, with the latter emphasising not only individual responsibility, but collective responsibilities of indigenous peoples towards their surrounding environment and ecosystems, ${ }^{62}$ and with the former arguing that rights and procedures in indigenous customary law stem from the community itself. ${ }^{63}$ In the New Zealand context, the Waitangi Tribunal has taken a similar approach in asserting the importance of whanaungatanga, drawing Māori responsibilities, obligations and relationships together through kinship between individuals, the group and the natural environment. ${ }^{64}$

A number of indigenous declarations on traditional knowledge have also stressed the importance of recognising indigenous collective rights in intellectual property. ${ }^{65}$ Finally, although collective rights are so broadly recognised and consistently present in indigenous customary law that they should be considered in any approach to defining misappropriation of traditional knowledge, they are not present in all indigenous customary law. The ritualised protection regime over traditional medicinal knowledge in South Asia illustrates this. There, the traditional healers utilised the regime to maintain control over their knowledge, in order to most effectively garner benefits from application of that knowledge. ${ }^{66}$ Having a localised approach enables tailoring to the laws of the particular indigenous group.

\section{A holistic approach}

A holistic approach entails endorsement of the worldview which forms the foundation of indigenous peoples' customary law. This goes further than a localised approach; in addition to recognising the particular customary law of indigenous peoples, this approach involves affirmation of the perspectives and principles inherent within this law. ${ }^{67}$ This approach has been recognised by

61 Wallace Coffey and Rebecca Tsosie "Rethinking the Tribal Sovereignty Doctrine: Cultural Sovereignty and the Collective Future of Indian Nations" (2001) 12 SLPR 191 at 197.

62 James Tully Public Philosophy in a New Key: Volume 1 - Democracy and Civic Freedom (Cambridge University Press, Cambridge, 2008) at 251

63 Borrows, above n 44, at 189.

64 Ko Aotearoa Tènei: Te Taumata Tuatahi, above n 1, at 105

65 See for example The Mataatua Declaration on Cultural and Intellectual Property Rights of Indigenous Peoples (July 1993), at [2.5]; Secretariat of the Pacific Community, Pacific Islands Forum Secretariat and UNESCO Pacific Regional Office, above n 55, art 4; and "COICA Statement" (2001) 6(1) AILR 107.

66 WIPO, above $\mathrm{n} 7$, at 59.

67 Krystyna Swiderska "Protecting Traditional Knowledge: A Holistic Approach Based on Customary Laws and Bio-cultural Heritage" in Karachepone Ninan (ed) Conserving and Valuing Ecosystem Services and Biodiversity: Economic, Institutional and Social Challenges (Earthscan, London, 2012) 331 at 333. 
WIPO in its fact-finding missions. ${ }^{68} \mathrm{~A}$ further compelling example is presented by the Waitangi Tribunal in both its Wai 167 and Wai 262 reports. In the former, the Tribunal noted that Māori place emphasis on the relationship of their mauri (lifeforce) with the mauri of parts of nature, such as rivers, lakes and mountains. ${ }^{69}$ It used this to discuss the notion of kaitiakitanga; an obligation to both care for and nurture the mauri of the environment, which is a communal aspect in that it is not the sole responsibility of an individual to protect the waterways and mountains, but that of the collective. ${ }^{70}$ In the latter, the Tribunal recognised the rangatiratanga of Māori, which it found ought to be reflected in the intellectual property system through protection of kaitiakitanga obligations and relationships between Māori and their taonga. ${ }^{71}$ Drahos and Frankel define this perspective as a "connectionist" worldview, as it captures the "densely networked" means in which indigenous peoples see the world. ${ }^{72}$ This approach is perhaps best described by the declaration of Shamans on traditional knowledge from the Brazilian Delegation to the WIPO-IGC: "[o]ur knowledge on biodiversity is not separate from our identities, our laws, our institutions, our system of values and our cosmological view as indigenous peoples". ${ }^{73}$

\section{Defining Misappropriation}

Misappropriation generally involves the wrongful or dishonest use of property. ${ }^{74}$ It is a particular concern of indigenous peoples with regard to their traditional knowledge. ${ }^{75}$ There is currently no international instrument with an express requirement to suppress misappropriation of traditional knowledge within the intellectual property context. ${ }^{76}$ However the scope in which the term is framed will be key to ensuring effective protection of indigenous traditional knowledge. ${ }^{77}$

68 WIPO, above $\mathrm{n} 7$, at 90 .

69 Waitangi Tribunal Whanganui River Report, above n 40, at 267.

70 At 39 .

71 Ko Aotearoa Tènei: Te Taumata Tuatahi, above n 1, at 80.

72 Drahos and Frankel, above n 25, at 16.

73 Intergovernmental Committee on Intellectual Property and Genetic Resources, Traditional Knowledge and Folklore Declaration of Shamans on Intellectual Property and Protection of Traditional Knowledge and Genetic Resources WIPO/GRTKF/IC/2/14 (12 December 2001) at 1.

74 Intergovernmental Committee on Intellectual Property and Genetic Resources, Traditional Knowledge and Folklore Glossary of Key Terms Related to Intellectual Property and Genetic Resources, Traditional Knowledge and Traditional Cultural Expressions WIPO/GRTKF/IC/22/INF/8 (27 April 2012) at 27.

75 William Fisher "The Puzzle of Traditional Knowledge" (2018) 67 Duke LJ 1511 at 1513.

76 IGC, above n 6, at 102.

77 United Nations Economic and Social Council Traditional knowledge: generation, transmission and protection E/C.19/2019/5 (6 February 2019) at 12. 
Misappropriation as a kind of unfair competition has been part of the intellectual property system through the Paris Convention for the Protection of Industrial Property, under which art 10bis compels signatory states to "assure to nationals ... effective protection against unfair competition". ${ }^{78}$ The United States Supreme Court discussed misappropriation as an aspect of unfair competition, reasoning that the plaintiff news company had a "quasi-property" interest in the news that it gathered which gave it the right to prevent competitors from using it. ${ }^{79}$ From a common law approach, misappropriation entails the wrongful use of the "property" of another. ${ }^{80}$

The issue of "biopiracy" provides an example of misappropriation in the context of indigenous traditional knowledge. ${ }^{81}$ Dutfield and Posey define biopiracy as the means by which entities take unfair advantage of the genetic resources and traditional knowledge of indigenous peoples. ${ }^{82}$ The principal concern of indigenous peoples with regard to biopiracy is that unauthorised access to or use of their traditional knowledge, such as for example, traditional medicines, by entities such as corporations, researchers or even the state, will often lead to that knowledge being inappropriately used or exploited for profit. ${ }^{83}$

Biopiracy is augmented by the fact that it is an effective means of misappropriation within the intellectual property system. ${ }^{84}$ For example, the underlying purpose of patent law is to encourage innovation by granting the inventor an exclusive right to exploit their invention for a limited period of time, after which the invention and method are disclosed. ${ }^{85}$ If traditional knowledge is utilised without the authorisation or knowledge of indigenous peoples as the basis for an invention, it may

78 Paris Convention for the protection of industrial property of March 20, 1883, as revised at Brussels on December 14, 1900, at Washington on June 2, 1911, at The Hague on November 6, 1925, at London on June 2, 1934, at Lisbon on October 31, 1958, and at Stockholm on July 141967828 UNTS 305 (as amended on September 28, 1979) (signed 14 July 1967, entered into force 26 April 1970), art 10bis.

79 International News Service v Associated Press 248 US 215 (1918).

80 IGC, above $\mathrm{n} 74$, at $27-28$

81 Vandana Shiva Biopiracy: The Plunder of Nature and Knowledge (South End Press, Boston, 1997).

82 Darrell Posey and Graham Dutfield Beyond Intellectual Property: Toward Traditional Resource Rights for Indigenous Peoples and Local Communities (International Development Research Centre, Ottawa, 1996) at 44.

83 Winston P Nagan "Misappropriation of Shuar Traditional Knowledge (TK) and Trade Secrets: A Case Study on Biopiracy in the Amazon" (2010) 15 IJTPL 9. See also Intergovernmental Committee on Intellectual Property and Genetic Resources, Traditional Knowledge and Folklore Patent System and the Fight Against Biopiracy - The Peruvian Experience WIPO/GRTKF/IC/8/12 (30 May 2005).

84 Teshager Dagne "The Protection of Traditional Knowledge in the Knowledge Economy: Cross-Cutting Challenges in International Intellectual Property Law" (2012) 14 Int C L Rev 137 at 143-145.

85 Ko Aotearoa Tēnei: Te Taumata Tuatahi, above n 1, at 169. 
still be patented if it meets the requirements for patentability in the Patents Act 2013, which include novelty, inventive step and utility. ${ }^{86}$

While a definition of misappropriation in the draft articles has not been conclusively determined, the WIPO-IGC offered alternative definitions at the 40th Session of the WIPO-IGC. This includes (amongst others) a definition of "misappropriation" as "any access to or use of traditional knowledge of the beneficiaries in violation of customary law and established practices governing the access or use of such traditional knowledge". ${ }^{87}$

There are several alternative definitions that impose either more onerous requirements on the traditional knowledge user (such as a definition similar to the one above, but with greater emphasis on prior, informed consent of the indigenous knowledge-holders) or definitions which significantly narrow the scope of what can be termed misappropriation (with greater focus on a breach of domestic laws). ${ }^{88}$ This signals the current lack of clarity in the WIPO-IGC due to differing levels of reluctance among states to implement indigenous customary law and sovereignty. ${ }^{89}$

\section{APPLICATION}

\section{A Application of Customary Law Approaches: Ascertaining a Definition for an International Instrument}

A definition of misappropriation which fails to consider indigenous customary law will be highly unlikely to provide adequate protection for traditional knowledge. The issue of biopiracy evidences this conclusion. Another specific example is the Smokebush, a species utilised by the indigenous peoples of Western Australia for its medicinal properties. ${ }^{90}$ The plant contains an active property called conocurovone, which could be used for treatment of HIV. ${ }^{91}$ Consequently, patents were filed by the United States National Cancer Institute for exclusive rights to use the compounds for treatment against HIV. ${ }^{92}$ Ultimately, the Western Australian Government negotiated a deal with the National Cancer Institute so that AMRAD (an Australian pharmaceutical company) could be licensed to have

86 For New Zealand patent requirements see Patents Act 2013, s 14.

87 IGC, above n 8, at 4 .

88 At 4.

89 Veronica Gordon "Appropriation Without Representation? The Limited Role of Indigenous Groups in WIPO's Intergovernmental Committee on Intellectual Property and Genetic Resources, Traditional Knowledge, and Folklore" (2014) 16 JETLaw 629 at 645.

90 Terri Janke "From smokebush to spinifex: Towards recognition Of Indigenous knowledge in the commercialisation of plants" (2018) International Journal of Rural Law and Policy 1 at 2.

91 At 2 .

92 At 2. 
an exclusive worldwide licence to develop the patent. ${ }^{93}$ It is unclear whether any scientific research on the plant's properties was triggered by awareness of indigenous use. But as noted by Drahos, the plant was known to be used by indigenous peoples for its medicinal properties. ${ }^{94}$ Thus traditional knowledge around the plant appeared to be held and developed collectively by local indigenous peoples.

As noted by Janke, the indigenous peoples of Australia hold collective obligations in relation to their knowledge, and often the species to which that knowledge relates. ${ }^{95}$ But in cases such as that of the Smokebush, it is difficult for indigenous peoples to adhere to their collective obligations by preventing their knowledge being derived and misappropriated. This is because their own knowledge may often have been already published or researched, and is thus part of the public domain and the "prior art base" (meaning that it cannot be patented).${ }^{96}$ Furthermore, patent applicants are able to build upon that indigenous knowledge in the public domain, to develop an invention that is "novel" for the purposes of patentability, to gain exclusive rights over a particular use of the species. ${ }^{97}$ Indigenous peoples are also unable to satisfy their collective obligations over aspects of their traditional knowledge using either trade mark or copyright protection due to those very obligations being collective. ${ }^{98}$

While the most recent definition proffered by the WIPO-IGC provides a starting point for protection of misappropriation, the three approaches (localised, holistic and collective) should be utilised to develop a more effective definition. One way this could occur is to take a dual approach by both re-drafting the definition of misappropriation and also introducing a new objective into the articles. With regard to the first part of this method, a definition of misappropriation which takes the three approaches into account may be phrased as:

Any access to or use of traditional knowledge of the indigenous peoples to whom the knowledge imposes an obligation upon, belongs to, or is protected by, either collectively or individually, which violates the

93 At 2 .

94 Peter Drahos Intellectual Property, Indigenous People and their Knowledge (Cambridge University Press, Cambridge, 2014) at 111.

95 Janke, above n 1, at 32.

96 Maiko Sentina, Elizabeth Mason and Terri Janke Legal Protection of Indigenous Knowledge in Australia: Supplementary Paper 1 (IP Australia and the Department of Industry, Innovation and Science, 2018) at 15. See also Doris E Long "Traditional Knowledge and the Fight for the Public Domain" (2006) 5 J Marshall Rev Intell Prop L 317; and Chidi Oguamanam "Wandering Footloose: Traditional Knowledge and the "Public Domain" Revisited" (2018) 21 J World Intellect Prop 306.

97 Sentina, Mason and Janke, above n 96, at 15.

98 Kathy Bowrey "Alternative Intellectual Property?: Indigenous Protocols, Copyleft and New Juridifications of Customary Practices" (2006) 6 Macquarie Law Journal 65 at 81. 
customary laws and principles of those peoples, whether those peoples consist of a single community, tribe, nation or ethnic group.

This upholds both localised and collective approaches by focusing on the violation of the customary laws and principles of the particular indigenous peoples from whom the traditional knowledge has been misappropriated, while also acknowledging that the knowledge may be held either individually or collectively. It also recognises the notion of indigenous peoples having customary obligations to protect traditional knowledge. With regard to the second part of this method, a new objective for the articles could be introduced, with the intention to:

Uphold the self-determination of indigenous peoples by empowering them to prevent misappropriation of their traditional knowledge when it is accessed and used in a manner which is a violation of their own customary law and principles derived from their particular values and worldview, fully acknowledging the distinctive nature of traditional knowledge systems, and the need to tailor solutions that meet the distinctive nature of such systems.

The purpose of this objective would be to ensure that when misappropriation has occurred, the party responsible for the act of misappropriation is aware of why their actions amount to a violation of the customary law and principles of the indigenous peoples to whom the knowledge is associated. Furthermore, this objective should assist in shaping the appropriate remedies, stemming from a consideration of the values which have been violated.

This objective is partially derived from two proposed objectives put forward at the 8th Session of the WIPO-IGC, with one objective concerning the protection of traditional knowledge, ${ }^{99}$ and the other concerning the protection of traditional cultural expressions. ${ }^{100}$ While the ambit of this thesis is mainly limited to traditional knowledge, the applicability of this proposed objective for protection of traditional cultural expressions is just as relevant to the protection of traditional knowledge. The proposed objective for traditional knowledge aims to: ${ }^{101}$

... be undertaken in a manner that empowers traditional knowledge holders to protect their knowledge by fully acknowledging the distinctive nature of traditional knowledge systems and the need to tailor solutions that meet the distinctive nature of such systems, bearing in mind that such solutions should be balanced and equitable, should ensure that conventional intellectual property regimes operate in a manner

99 Intergovernmental Committee on Intellectual Property and Genetic Resources, Traditional Knowledge and Folklore The Protection of Traditional Knowledge: Revised Objectives and Principles WIPO/GRTKF/IC/8/5 (June 2005).

100 Intergovernmental Committee on Intellectual Property and Genetic Resources, Traditional Knowledge and Folklore The Protection of Traditional Cultural Expressions/Expressions of Folklore: Revised Objectives and Principles WIPO/GRTKF/IC/8/4 (June 2005).

101 IGC, above n 99, at 5. 
supportive of the protection of traditional knowledge against misappropriation, and should effectively empower traditional knowledge holders to exercise due rights and authority over their own knowledge.

The proposed objective for traditional cultural expressions aims for protection to: ${ }^{102}$

... be achieved in a manner that is balanced and equitable but yet effectively empowers indigenous peoples and traditional and other cultural communities to exercise rights and authority over their own traditional cultural expressions/expressions of folklore.

Neither of these objectives has been included in the definition of the draft articles (as at the 40th Session of the WIPO-IGC). ${ }^{103}$ Instead, both of the draft articles for the protection of traditional knowledge and traditional cultural expressions include in their objectives this statement: ${ }^{104}$

Recognizing the need for new rules and disciplines concerning the provision of effective and appropriate means for the enforcement of rights relating to traditional knowledge, taking into account differences in national legal systems.

This lacks any direct reference to customary law and does little to compel states to introduce legislation that will provide indigenous peoples the autonomy to enforce their own customary law. In fact, the objective arguably places more emphasis on maintaining the status quo by prioritising recognition of "differences in national legal systems" over customary law. This is exacerbated by a further objective which stresses the need to preserve the public domain, ${ }^{105}$ without recognising that the introduction of traditional knowledge into the public domain itself (sometimes through misappropriation) is a significant issue that indigenous peoples have with the intellectual property system. ${ }^{106}$ Conversely, the fact that one of the alternative definitions of misappropriation defines it as being "any access to or use of traditional knowledge ... in violation of customary law", 107 could be considered as being a sufficient reference to customary law, and enough to allow states to empower indigenous peoples to apply their own custom to issues of misappropriation. However given that this definition is only one of five possible alternative definitions for misappropriation, and that it does not empower indigenous peoples to apply their own worldview, it would better advance the interests of

102 At 5 .

103 IGC, above $\mathrm{n} 8$.

104 At 2 .

105 At 2.

106 Brendan Tobin "Now you see it, now you don't: the rise and fall of customary law in the IGC" in Daniel Robinson, Ahmed Abdel-Latif and Pedro Roffe (eds) Protecting Traditional Knowledge: The WIPO Intergovernmental Committee on Intellectual Property and Genetic Resources, Traditional Knowledge and Folklore (Routledge, Abingdon (UK), 2017) 192 at 199.

107 IGC, above $\mathrm{n} 8$, at 4 . 
indigenous peoples if the recommended objective and definition of misappropriation were instead utilised in the draft articles.

Both Solomon and Tobin have argued that these more recent objectives of the 40th Session are a regression from those that were proposed at the 8th Session. Solomon suggests that these earlier proposed objectives were the "closest ... to the development of policies ... that would have provided ... some of the 'protections' that indigenous peoples have been calling for". ${ }^{108}$ Importantly, Solomon also indicates that those proposed objectives represented the cumulative effort of WIPO's fact-finding missions, state submissions and interventions by indigenous peoples occurring in the late 1990s. ${ }^{109}$ These findings appeared to become less relevant as the language regressed from the 8 th Session onwards, shifting towards more neutral language intended to entrench the IP regime status quo. ${ }^{110}$ Tobin notes that after making significant progress in the 8th Session, leaning towards a sui generis regime for protection of traditional knowledge with a fundamental role for customary law, the WIPOIGC has "veered sharply" away from this, now moving towards a "hybridised intellectual property style system devoid of any significant role for customary law". ${ }^{111}$ According to Tobin, this signifies a "backward step" in the progressive recognition of customary law and its role in the protection of traditional knowledge. ${ }^{112}$

Before analysis of domestic application, it is worth noting that the WIPO-IGC has posited three arguments against the notion that intellectual property and indigenous customary law are incompatible. ${ }^{113}$ Firstly, the WIPO-IGC provided examples of intellectual property legislation or cases effective in protecting indigenous traditional knowledge from misappropriation, ${ }^{114}$ including the Australian cases of Bulun Bulun v R \& T Textiles Pty Ltd and Milpurrurru v Indofurn Pty Ltd (discussed in detail below). ${ }^{115}$ Secondly, the WIPO Secretariat has rejected the argument that traditional knowledge cannot be protected under the IP regime, due to a significant portion of that

108 Solomon, above n 5, at 223.

109 At 223 .

110 At 226-227; and Gordon, above n 89, at 644.

111 Tobin, above n 106, at 208.

112 At 208 .

113 Intergovernmental Committee on Intellectual Property and Genetic Resources, Traditional Knowledge and Folklore Elements of a Sui Generis System for the Protection of Traditional Knowledge WIPO/GRTKF/IC/3/8 (June 2002) at 11.

114 At $11-12$.

115 At 11-12. See Bulun Bulun, above n 43; and Milpurrurru, above n 43. 
knowledge being "old" or in the public domain. ${ }^{116}$ Instead, the Secretariat emphasised that just because traditional knowledge is "traditional", it is not necessarily old. ${ }^{117}$ The Secretariat stressed that traditional knowledge continues to be produced today, and that it may still in fact be novel, even if it was developed many generations ago. ${ }^{118}$ This is evident in patent law, where an invention may be considered novel if it has not been disclosed or made available to the public. ${ }^{119}$ Finally, the WIPOIGC noted that communal ownership of indigenous traditional knowledge and the IP regime are not completely at odds, acknowledging that many intellectual property assets, particularly trade marks, are owned by collective entities. ${ }^{120}$

The WIPO-IGC is right to recognise that the IP regime and indigenous traditional knowledge are not wholly incompatible. However, while the IP regime can certainly implement aspects of customary law and can protect elements of indigenous traditional knowledge, it remains to be seen whether traditional knowledge as a whole can be protected. A significant portion of traditional knowledge is in fact in the public domain, or would not necessarily meet patent law's requirements for novelty or inventive step, possibly due to the very fact of it having been misappropriated earlier. ${ }^{121}$ Furthermore, as the WIPO-IGC recognises, the potential of intellectual property mechanisms such as patents, trade marks, and copyright to protect particular individualised elements of a piece of traditional knowledge does not necessarily either take into account the fact that certain elements of traditional knowledge will not be protected while others are, and fails to recognise the holistic nature of traditional knowledge. ${ }^{122}$ As stated by the WIPO-IGC: ${ }^{123}$

Traditional knowledge is not the mere sum of its separated components: traditional knowledge is more

than that - it is the consistent and coherent combination of those elements into an indivisible piece of knowledge and culture.

Finally, it fails to consider an important but perhaps overlooked fact: that intellectual property and traditional knowledge and customary law stem from different worldviews, and thus perhaps ought to be treated and protected differently. The above analysis indicates that application of either the chosen

116 Intergovernmental Committee on Intellectual Property and Genetic Resources, Traditional Knowledge and Folklore Survey on Existing Forms of Intellectual Property Protection for Traditional Knowledge Preliminary Analysis and Conclusions WIPO/GRTKF/IC/2/9 (3 December 2001) at 8.

117 At 8 .

118 At 9.

119 At 8.

120 At 8.

121 Sentina, Mason and Janke, above n 96, at 15.

122 IGC, above n 113, at 14; and Ko Aotearoa Tēnei: Te Taumata Tuatahi, above n 1, at 38.

123 IGC, above n 113, at 14. 
WIPO-IGC definition, or the definition recommended in this article, will cause some difficulties, as both definitions are located in different parts of the intellectual property-indigenous customary law interface. The chosen definition is more amenable to the current IP regime, but affords less recognition of customary law, while the recommended definition may require greater amendment to the IP regime, but better upholds the customary law approaches.

\section{B Application of the Definition at National Level}

In order to determine how effective the recommended definition might be, particularly in upholding the three aforementioned customary law approaches (and potentially the self-determination of indigenous peoples), its possible application at national or domestic level ought to be considered. This article applies the recommended definition by considering the indigenous customary law, traditional knowledge issues and legal framework of two states that have been involved in the WIPOIGC draft articles process, and are currently grappling with the issue of traditional knowledge misappropriation. ${ }^{124}$ Through a comparison of the current domestic legal protections of these states against misappropriation with the standards set out in the proposed definition, conclusions on the effectiveness of this definition in state practice can be derived.

\section{New Zealand: An introduction}

The legal governance and protection of mātauranga Māori in New Zealand is set out within the confines of the IP regime. Alongside the development of the common law through judicial decisions, intellectual property is mainly governed through three statutes: The Patents Act 2013, Trade Marks Act 2002 and Copyright Act 1994. New Zealand is also a party to various international instruments, including The Agreement on Trade-Related Aspects of Intellectual Property Rights (TRIPS Agreement), ${ }^{125}$ and has been a participant in the WIPO-IGC draft articles negotiations. Williams J, in his extrajudicial writing, provides perhaps the most succinct description of the current New Zealand legal system with his phrase "Lex Aotearoa". ${ }^{126}$ According to Williams J, there have been three legal systems in this country: the first law, or "Kupe's Law", ${ }^{127}$ which was tikanga Māori, the second law,

124 Te Puni Kōkiri Ministry of Māori Development Wai 262 - Te Pae Tawhiti: The role of the crown and māori in making decisions about taonga and mātauranga māori - Preliminary proposals for Crown organisation (August 2019) at 23; and Maiko Sentina and others International Laws and Developments relating to Indigenous Knowledge in Australia: Supplementary Paper 2 (IP Australia and the Department of Industry, Innovation and Science, 2018) at 5.

125 Marrakesh Agreement Establishing the World Trade Organization 1867 UNTS 3 (opened for signature 15 April 1994, entered into force 1 January 1995), Annex 1C (Agreement on Trade-Related Aspects of Intellectual Property Rights) [TRIPS Agreement].

126 Joseph Williams "Lex Aotearoa: An Heroic Attempt to Map the Māori Dimension in Modern New Zealand Law" (2013) 21 Waikato L Rev 1.

127 Jacinta Ruru "First Laws: Tikanga Māori in/and the Law" (2018) 49 VUWLR 211. 
or "Cook's Law", ${ }^{128}$ which was the common law, and the third and current law, "Lex Aotearoa", which draws on both its predecessors. ${ }^{129}$ Despite this, tikanga is not equally applied as the common law; nor is there a comprehensive sui generis regime in place. Instead, the statutes incorporate certain requirements to take mātauranga Māori into consideration.

This issue is discussed in the context of the Wai 262 report. However, it is worth reiterating the fundamental principles that underpin tikanga and mātauranga Māori. Ultimately, Māori traditional knowledge, and the customary law which governs that knowledge, is a communal system which places significant emphasis on the relationship and obligations with natural resources and species. ${ }^{130}$ Under a Māori worldview, there is a direct whakapapa with those natural resources or species as tupuna (ancestors), which in turn indicates that the mātauranga Māori, or knowledge developed from those resources, is not a commodity to be owned or sold, but a taonga of that tupuna to be protected. ${ }^{131}$ This is best described by the Waitangi Tribunal in its report on the Whanganui River, where it noted that the worldview of the Whanganui iwi to the River was that it could not be owned, ${ }^{132}$ as a taonga inherently connected to the iwi: ${ }^{133}$

The river, like the land, was transmitted from ancestors, from the original ancestress, Papat[ūā]nuku, the earth mother, through the first people to the current occupying tribes, and was bound to pass to the tribes' future generations. For the same reason, the river, like the land, was not a tradeable item.

\section{New Zealand: Wai 262 and patents}

The Wai 262 report provides useful quasi-judicial recommendations on the protection of mātauranga Māori from misappropriation, as well as identifying when that misappropriation may violate tikanga. While these recommendations are not legislative in nature, they have partially influenced the provisions which protect traditional knowledge from misappropriation under the Patents Act. In its approach, the Tribunal sought to make recommendations which recognised the interface between the IP regime and mātauranga Māori. ${ }^{134}$ While it acknowledged that protection of mātauranga Māori was somewhat limited within the confines of the intellectual property system, it

128 Ruru, above n 127.

129 Williams, above n 126, at 2.

130 For examples of the importance of this relationship see Waitangi Tribunal Whanganui River Report, above $\mathrm{n}$ 40, at 35, 38 and 56-58; Waitangi Tribunal Te Whanganui-A-Orotu Report 1955, above n 40, at 201; Waitangi Tribunal Te Urewera Report Part V, above n 40, at 30-38; and Ko Aotearoa Ténei: Te Taumata Tuatahi, above $\mathrm{n} 1$, at 67-68.

131 Ko Aotearoa Tēnei: Te Taumata Tuatahi, above n 1, at 22-23.

132 Waitangi Tribunal Whanganui River Report, above n 40, at 46.

133 At 48

134 Ko Aotearoa Tēnei: Te Taumata Tuatahi, above n 1, at 31. 
stressed the importance of the right of Māori to exercise kaitiakitanga over their traditional knowledge. ${ }^{135}$ In doing so, the Tribunal made three key recommendations.

Firstly, it recommended that disclosure requirements be implemented in patent applications requiring disclosure of whether mātauranga Māori has contributed to the research or invention in any way (such as research into the medicinal properties of plants used in traditional Māori medicine), with consequences for failure to disclose, which included sanctions or revocation of the patent. ${ }^{136}$ Secondly, to assist with the first recommendation, the Tribunal also suggested the creation of a register where Māori could formally demonstrate and notify parties of their kaitiaki interest in taonga species. ${ }^{137}$ Finally, the Tribunal recommended that a Māori Patents Advisory Committee be established to register and advise on kaitiaki interests in taonga species. ${ }^{138}$ This was introduced (albeit in an attenuated form) into the Patents Act under s 15(3), which empowers the Commissioner of Patents to seek advice from the Māori Patents Advisory Committee when considering whether an invention is contrary to morality or ordre public (public policy).

If all three recommendations had been adopted within the Patents Act, this legislation would exhibit some characteristics of a localised, collective and holistic approach towards misappropriation as a violation of indigenous customary law. While s 15(3) does allow for a partially holistic approach by empowering a Māori Advisory Committee to recommend what might be misappropriation based on tikanga, the Tribunal's other two recommendations were not included within the legislation. The combined registration of kaitiaki interests and patent disclosure would have allowed hapu or iwi with kaitiaki obligations to a taonga species or work at least partially uphold those obligations. They would be specifically identified as the kaitiaki to which parties would have to disclose use of mātauranga Māori to (with consequences for failure to disclose) and to a Māori Patents Advisory Committee with greater adjudicative (and binding) powers, may have been able to object to and prevent registration of patents contrary to the particular tikanga of that group.

Had the three recommendations been fully implemented, a localised approach would have been more likely, as the specific recognition of iwi or hapū as kaitiaki empowered by a Māori Advisory Committee with broader and binding powers, may have allowed for greater acknowledgment and application of the particular tikanga of that group in consideration of patent registration. However, Lai does note that the challenge inherent in specifically registering the obligations of groups such as hapu is that kaitiaki interests or obligations in taonga species can spread across a range of groups, and not all of these groups may have adequate legal and economic capacity to oppose or investigate

135 At 85 .

136 At 212

137 At 212

138 At 212 
registration. ${ }^{139}$ However, this issue was in fact considered by the Tribunal, which noted that registration of local kaitiaki groups such as hapu will not address national issues - such as where there is proposed genetic modification of a taonga species. ${ }^{140}$ The Tribunal recommended that a national body representing the interests of kaitiaki nationwide be established to deal with broader issues of mātauranga Māori misappropriation and capacity issues and that it would be "for Māori themselves to develop such a body as they see fit". ${ }^{141}$ Notably, although a wider body does not at first glance appear to support a localised approach, if it worked in tandem with a register of local kaitiaki, it could have the effect of actually promoting an even greater focus on localised tikanga Māori.

Furthermore, if implemented properly, the recommendations may have upheld a collective approach. This is because a kaitiaki register would allow for recognition of a collective interest in the mātauranga Māori of a taonga species or work, held by particular iwi or hapū. The particular group could also, through the Māori Patents Advisory Committee or the disclosure process, collectively object to registration. One particular aspect of the recommendations is that they stress a collective obligation of kaitiakitanga as opposed to a collective right of ownership. ${ }^{142}$ On one hand, this is a useful, practical approach as it acknowledges that under tikanga Māori, kaitiakitanga over mātauranga Māori does not necessarily sit comfortably with the notion of exclusive individualised ownership. ${ }^{143}$ It is, as expressed through this article, perhaps more accurate to define indigenous (particularly Māori) interests in traditional knowledge as collective obligations, rather than individual rights. ${ }^{144}$ This is aptly summarised by the Tulalip Tribes of Washington, who state that: ${ }^{145}$

For the M[ā]ori, as lawyer Maui Solomon has emphasized, it makes no sense to talk about rights without also talking about obligations for the use of knowledge and resources, and this view is common, if not universal, among indigenous peoples. Although individuals might hold knowledge, their right is collectively determined ...

The Tribunal appears to be recognising this dichotomy through its recommendation of a kaitiaki interest and the obligations that this may entail. On the other hand, perhaps the most significant

139 Jessica C Lai Māori Traditional Knowledge and the Wai 262 Report: A Coherent Way Forward? (University of Lucerne, Working Paper No 2012/03, 2012) at 25.

140 Ko Aotearoa Tēnei: Te Taumata Tuatahi, above n 1, at 94.

141 At 94 .

142 At 50 .

143 At 50.

144 Jessica C Lai Indigenous Cultural Heritage and Intellectual Property Rights (Springer International Publishing, Switzerland, 2014) at 65.

145 World Intellectual Property Organization Intergovernmental Committee on Intellectual Property and Genetic Resources, Traditional Knowledge and Folklore Statement By the Tulalip Tribes of Washington on Folklore, Indigenous Knowledge, and the Public Domain (9 July 2003) at 2. 
critique of this recommendation is that although it does uphold a collective approach, it may not go far enough to allow Māori to broadly enforce their collective kaitiaki obligations. This is because, as discussed above, the IP regime places emphasis on property rights as being the ultimate, or most effective, form of protection against misappropriation. Therefore, the most effective way to achieve the recommended objective is to apply kaitiaki-based obligations that are more akin to property rights, to protect against misappropriation. This is discussed in greater detail below.

\section{New Zealand: Wai 262 - trade mark and copyright}

The Tribunal also made recommendations concerning mātauranga Māori, "taonga works" and their protection through trade mark and copyright law. Taonga works were defined as works created through the pre-existing and distinctive body of mātauranga Māori, which had their own whakapapa, or lineage, leading to kaitiaki obligations in the present. ${ }^{146}$ These were distinguished by the Tribunal from "taonga-derived works", which are not in their entirety an expression of mātauranga Māori or invocation of whakapapa. ${ }^{147}$ The Tribunal made two key recommendations concerning these works. Firstly, two differing legal mechanisms should be introduced. The first mechanism would allow for any person to object to the derogatory or offensive public use of taonga works, taonga-derived works or mātauranga Māori. ${ }^{148}$ This would uphold cultural integrity, and consequently the kaitiaki interest, by ensuring that taonga works, such as tā moko, are not utilised in offensive ways. ${ }^{149}$ The second mechanism would allow for kaitiaki to prevent any commercial exploitation of taonga works or mātauranga Māori (but not taonga-derived works, because they are not in their entirety an expression of mātauranga Māori), unless there has been consultation and where appropriate, kaitiaki consent. ${ }^{150}$ By limiting this second mechanism to taonga works and only allowing kaitiaki to object, the Tribunal provides a balance between the kaitiaki interest and relationship with important cultural works such as tā moko, and the rights of private intellectual property owners and the public to continue to benefit from Māori culture when appropriate. ${ }^{151}$

The second recommendation concerned the establishment of an expert commission that would have wide adjudicative and facilitative functions concerning the kaitaiki interests in taonga works. ${ }^{152}$ It would allow for the creation of a kaitiaki register similar to that discussed above, and provide a forum for determining whether a particular work was in fact a taonga work, who had kaitiaki interests

146 Ko Aotearoa Tēnei: Te Taumata Tuatahi, above n 1, at 30.

147 At 47.

148 At 99.

149 At 88.

150 At 99.

151 At 91.

152 At 99. 
in it, and whether it had been misappropriated. ${ }^{153}$ The commission would be multi-disciplinary, consisting of members with significant expertise in mātauranga Māori, intellectual property and science, and would replace the current Māori Trade Marks Advisory Committee. ${ }^{154}$ Neither of these recommendations has been implemented by the Crown. Instead, two provisions in the Trade Marks Act provide some minimal protection for mātauranga Māori against misappropriation.

Section 17(1)(c) of the Trade Marks Act allows Māori to object to trade marks which they deem offensive, and if the Commissioner of Trade Marks concurs (on advice of the Māori Trade Marks Advisory Committee), ${ }^{155}$ then the trade mark must not be registered. ${ }^{156}$ The provision effectively represents the interface between intellectual property and mātauranga Māori; it enables at least some protection of mātauranga Māori in the intellectual property system without fully undermining that system. However, in Wai 262, the Tribunal recognised that while s 17(1)(c) is a "worthwhile" provision which prevents the registration of offensive Māori words, images or texts, ${ }^{157}$ it does not protect mātauranga Māori overall. ${ }^{158}$ For example, the Tribunal discussed the story of Tamatea Pokai Whenua, whose story gave rise to the longest place name in the world and had significant cultural importance to local iwi. ${ }^{159}$ Despite this, under the current intellectual property system and trade mark law, Māori were unable to register the place name itself for protection. ${ }^{160}$ This reflects the fact that the provision cannot fully protect mātauranga Māori from potential exploitation within the intellectual property system.

Furthermore, s 178 of the Trade Marks Act empowers a Māori Advisory Committee to advise the Commissioner whether the use or registration of a trade mark would be offensive to Māori. It works in tandem with s 17(1)(c), as the Committee advises the Commissioner on objections to trade mark registration under that provision. The Committee has been relatively proactive in that it has not only advised the Commissioner on when a mark may be offensive, but has also issued broad guidelines on what may or may not be offensive to Māori, such as recommending that where a pitau (koru) appears as in a mark, it will not be offensive for a wide range of goods and services. ${ }^{161}$ However the role of

153 At $99-100$.

154 At 99 .

155 Trade Marks Act 2002, s 178.

156 Trade Marks Act, s 17(1)(c).

157 Ko Aotearoa Tēnei: Te Taumata Tuatahi, above n 1, at 64.

158 At 64 .

159 At 38 .

160 At 38 .

161 New Zealand Intellectual Property Office Terms of Reference for the Māori Trade Marks Advisory Committee (Ministry of Business, Innovation and Employment) at 2. 
the Committee differs significantly to what was recommended in Wai 262. The Committee lacks binding powers, and does not have the broad, adjudicative and facilitative function intended by the Tribunal. ${ }^{162}$ Instead, it serves only an advisory function and does not have the capacity to facilitate mechanisms which could be useful in protecting against misappropriation, such as a kaitiaki register. ${ }^{163}$

\section{New Zealand: Wai 262 - a brief case study (mānuka)}

The significant research and development that has been invested into the medical and therapeutic effects of mānuka illustrates the constraints of the current IP regime in New Zealand. In Wai 262, the Tribunal noted that patents for different therapeutic and medical uses of mānuka had been successfully applied for, including patents from Germany. ${ }^{164}$ The issue of patents concerning mātauranga Māori and mānuka has been investigated by Lai. ${ }^{165}$ In her assessment of patent applications over mānuka ${ }^{166}$ before 31 March 2018, Lai provides some potential critiques of the current IP regime (namely the patent registration process), showcasing how currently, it may be unlikely to adhere to the recommended definition of misappropriation in this article.

Lai's critique focuses on the Patents Māori Advisory Committee and its functions and constraints under s 226 of the Patents Act, an arguably watered-down provision of what the Waitangi Tribunal actually recommended in Wai $262 .{ }^{167}$ The Committee may only give advice to the Commissioner on whether an invention claimed in a patent application is derived from Māori traditional knowledge or from indigenous plants or animals, and if so, whether the commercial exploitation of that invention is likely to be contrary to Māori values. ${ }^{168}$ Effectively, the Committee's powers are limited to considering derivation and commercial exploitation contrary to Māori values. ${ }^{169}$ These are somewhat vague, but also narrow terms. There is currently no definition of what "Māori values" encompass, ${ }^{170}$ although this would likely be determined by the Committee, which does consist of members, who, in the opinion of the Commissioner, are qualified for appointment, having regard to their knowledge of

162 Ko Aotearoa Tènei: Te Taumata Tuatahi, above n 1, at 99.

163 New Zealand Intellectual Property Office "Māori words and designs" <www.iponz.govt.nz/about-ip/maori-ip>.

164 Ko Aotearoa Tènei: Te Taumata Tuatahi, above n 1, at 67.

165 Jessica C Lai "A successful recalibration of patent law vis-à-vis mātauranga māori? a case study of Mānuka (leptospermum scoparium)" in Susy Frankel (ed) The Object and Purpose of Intellectual Property (Edward Elgar Publishing, Cheltenham (UK), 2019) 30.

166 Lai also assessed patents with the scientific name for mānuka: Leptospermum scoparium.

167 Ko Aotearoa Tēnei: Te Taumata Tuatahi, above n 1, at 212.

168 Patents Act, s 226.

169 Lai, above n 165, at 38.

170 At 37. 
mātauranga and tikanga Māori. ${ }^{171}$ The Committee also appears to have signalled that it will release guidelines concerning "Māori values" in the near future. ${ }^{172}$ While an attempt to define all tikanga Māori relevant to this area may be impractical, Lai rightly expresses concern that there is a lack of a framework or guidelines concerning how tikanga Māori might apply, given the critical fact that some patent applications or registrations are from groups who may have little knowledge of mātauranga Māori and how their patents should be used under tikanga Māori. ${ }^{173}$ This also illustrates the issue with the highly ambiguous phrasing "derived from Māori traditional knowledge or indigenous plants and animals". ${ }^{174}$ Firstly, the fact that there is no single definition of traditional knowledge is welldocumented. Secondly, the meaning of "indigenous plants and animals" is unclear: this does not appear to include micro-organisms, and could in fact exclude mānuka, which despite its traditional use by Māori, is also indigenous to Australia. ${ }^{175}$ Thirdly, there is no definition or threshold for derivation, suggesting that there is no framework to assist the Māori Advisory Committee in determining what may or may not be derived from a taonga species or mātauranga Māori. ${ }^{176}$ Fourthly, the Committee may only advise when the commercial exploitation of the invention is likely to be contrary to Māori values, but not the invention itself. ${ }^{177}$

The lack of clarity in this area only further serves to weaken an already watered-down provision, as the narrow, yet also ambiguous terms make it difficult both for applicants to identify when and how they should appropriately utilise mātauranga Māori, and also for the Committee to identify when and how mātauranga Māori is being used inappropriately under the rules in the statute. This is rendered even more ineffective without a kaitiaki register, which would at least bring in greater input and oversight from hapū and iwi with kaitiaki obligations and interests over mātauranga Māori or taonga species and works. However even if a register was implemented, without a Committee with broader and binding functions, misappropriation could still occur through the patent registration system. Lai notes that since the entry into force of the Patents Act, the Intellectual Property Office of New Zealand (IPONZ) application form has required that patent applicants indicate with a "yes/no" whether their application has a "Māori conflict possible" and whether it uses "traditional knowledge". ${ }^{178}$ These

171 Patents Act, s 225.

172 Lai, above n 165, at 37. See also New Zealand Intellectual Property Office Protecting intellectual property with a Māori cultural element: User Guide (Ministry of Business, Innovation and Employment, June 2016) at 23 .

173 Lai, above n 165 , at 44 .

174 Patents Act, s 226.

175 Lai, above n 165, at 37.

176 At 37.

177 At 38 .

178 At 38 
terms are not defined in the application, and are optional; it is not compulsory for the applicant to answer them. ${ }^{179}$ Therefore, those applicants with a lack of understanding of mātauranga Māori, or those perhaps unwilling to indicate that their invention is at all derived from or utilises mātauranga Māori, may select "no" without further explanation. In the context of mānuka, all of the four applications filed after the Patents Act entered into force indicated that there was neither "Māori conflict possible" nor "traditional knowledge". ${ }^{180}$ Lai suggests that this results from a poor understanding of what "Māori conflict possible" or "traditional knowledge" means, or even may be "a consequence of the lack of any incentive to answer the questions honestly". ${ }^{181}$ It is worth noting that the Māori Patents Advisory Committee, since its conception, has not had a single application sent to it. ${ }^{182}$

It is not clear whether there is any connection between patents of this type and rongoā Māori (Māori medicine), or other forms of mātauranga Māori. However the inability of the Patents Advisory Committee to investigate whether patents of this type actually satisfy the requirements of novelty, or inventive step (or whether they are in fact based on some form of mātauranga Māori), combined with the lack of a kaitiaki interest register, which would provide greater clarity for both inventors and the Committee as to the collective rights of Māori groups over taonga species. This illustrates the potential difficulty that indigenous peoples may have if the suggested definition of misappropriation is not applied properly.

\section{New Zealand: sui generis regime}

Upon analysis of the current New Zealand legislative framework, and the only partial implementation of the recommendations of the Waitangi Tribunal's Wai 262 report, the incorporation of the recommended definition discussed above may require a significant legislative and policy shift away from the status quo. In order to more effectively adhere to the recommended definition and objective discussed above, New Zealand could develop its law based on two distinct options.

Firstly, those remaining recommendations from Wai 262 not currently in law could be implemented. They would likely be effective in at least forming the foundation of a sui generis framework against misappropriation consistent with the three customary law approaches. This is discussed in detail above, in relation to patents and trade marks over mātauranga Māori, taonga works and taonga species. As explicitly recognised by the Tribunal, the aim of the Wai 262 report was not to advocate for the complete rejection and dissolution of the intellectual property system as a whole,

179 At 38.

180 At 54.

181 At 54.

182 Jessica C Lai and others "Māori knowledge under the microscope: appropriation and patenting of mātauranga māori and related resources" (2019) 22 J World Intellect Prop 205 at 220. 
but rather to seek solutions and recommendations which better balanced the intellectual property system and tikanga, and would give greater effect to the tino rangatiranga of Māori. ${ }^{183}$ One of the significant benefits of implementing these recommendations is that they would provide at least the foundations of a system that supports and upholds tino rangatiratanga. This is because all of the recommendations, fully implemented, would allow for a localised, collective and holistic approach which supports the autonomy of hapū and iwi. With all recommendations implemented, iwi and hapū would be able to register their interests as kaitiaki in mātauranga Māori, taonga works and taonga species, based on their whakapapa and kaitiakitanga relationships, object to commercial exploitation or derogatory use contrary to their tikanga, and rely on an advisory committee with binding functions to facilitate an appropriate tikanga-based response, ultimately upholding their mana and rangatiratanga. Their particular localised customary laws, collectively held, could be applied. This situation would bring New Zealand's legal protections against misappropriation closer towards what Solomon terms a "tikanga framework": ${ }^{184}$

Developed by Māori after appropriate consultation with Iwi, hapū, whanau and urban Māori groups and other relevant Māori organisations [namely through the Wai 262 process] ... [b]ased primarily in tikanga Māori, reflecting Māori cultural values and practices but also taking into account existing legislative and regulatory frameworks, international human rights norms and law ...

The second option is to protect against misappropriation of traditional knowledge through the establishment of a property right for Māori over their mātauranga Māori. For example, Carpenter, Katyal and Riley have argued that the current academic conception of indigenous cultural property is too narrow. ${ }^{185}$ The current jurisprudence, according to Carpenter, Katyal and Riley, only focuses on traditional, western constructs of property, deeming property rights themselves to be an ill-fitting mechanism for giving effect to indigenous rights over traditional knowledge. ${ }^{186}$ Instead, indigenous peoples ought to utilise a broader assessment of property which: ${ }^{187}$

...transcends the classic legal concepts of markets, title, and alienability that we often associate with ownership, making it all the more important for property scholars to evaluate its parameters ... a more relational vision of property law honours the legitimate interests of both owners and nonowners, in furtherance of various human and social values, potentially including nonmarket values.

183 Ko Aotearoa Tēnei: Te Taumata Tuatahi, above n 1, at 55-56.

184 Intergovernmental Committee on Intellectual Property and Genetic Resources, Traditional Knowledge and Folklore The Protection of Traditional Cultural Expressions/Expressions of Folklore: Table of Written Comments on Revised Objectives and Principles WIPO/GRTKF/IC/11/4(B) (19 April 2007) at 31.

185 Kristen A Carpenter, Sonia K Katyal and Angela R Riley "In Defense of Property" (2009) 118 Yale LJ 1022.

186 At $1026-1027$.

187 At 1027. 
Carpenter, Katyal and Riley advocate for a form of property right based on indigenous cultural property, termed as "cultural stewardship". ${ }^{188}$ This does not override property, but instead rejects the notion that the bundle of rights which forms the theoretical foundation for the effective supremacy of property rights should not be considered absolute, but rather as relative entitlements balanced against the cultural property rights of indigenous peoples. ${ }^{189}$ A compelling aspect of Carpenter, Katyal and Riley's alternative conception of property rights is that it places significant emphasis on the importance of the obligations that are placed upon indigenous peoples over their natural resources and knowledge by dint of their whakapapa. ${ }^{190}$ That justification reflects a consistent theme running throughout this article: that indigenous customary law tends to emphasise obligations to, rather than rights over, traditional knowledge - and that an effective customary law-compliant definition consistent with a holistic, localised and collective approach would acknowledge this tendency in its application.

Okediji also supports the use of property rights in a sui generis system to protect indigenous traditional knowledge from misappropriation. However, this is based on a traditional conception of property rights for certain categories of traditional knowledge. ${ }^{191}$ This is a tiered approach: secret, sacred or closely held traditional knowledge ought to be protected through property rights, ${ }^{192}$ while widely held or "diffused traditional knowledge" is protected through rights of attribution (such as the moral rights afforded to creators of copyright works), ${ }^{193}$ and publicly available traditional knowledge is given no protection, as it is in the public domain. ${ }^{194}$ While this tiered approach (presented to the WIPO General Assembly by the African Delegation in 2014) ${ }^{195}$ has a pragmatic, realist appeal, ${ }^{196}$ Carpenter, Katyal and Riley's recommendations are arguably more consistent with the customary law

188 At 1067.

189 At 1066.

190 At 1068.

191 Okediji, above n 10, at 305. See also Chidi Oguamanam Tiered or Differentiated Approach to Traditional Knowledge and Traditional Cultural Expressions: The Evolution of a Concept (Centre for Governance and Innovation, CIGI Papers No 185, August 2018).

192 Okediji, above n 10, at 306 .

193 At 306.

194 At 306 .

195 At 304. See also Intergovernmental Committee on Intellectual Property and Genetic Resources, Traditional Knowledge and Folklore Report of the Twenty-Seventh Session of the Intergovernmental Committee on Intellectual Property and Genetic Resources, Traditional Knowledge and Folklore WIPO/GRTKF/IC/27/10 (2 July 2014).

196 Intergovernmental Committee on Intellectual Property and Genetic Resources, Traditional Knowledge and Folklore Report of the Thirty-Ninth Session of the Intergovernmental Committee on Intellectual Property and Genetic Resources, Traditional Knowledge and Folklore WIPO/GRTKF/IC/39/18 (17 June 2019) at 17. 
approaches in a New Zealand context. This is because as stressed above, their conception of how property rights for indigenous peoples' traditional knowledge might be developed in a sui generis regime places greater emphasis on guardianship/kaitiakitanga, and whakapapa based obligations. The Waitangi Tribunal has similarly recognised that Māori ought to have rights in water recognised as akin to "English-style ownership" as a result of their intrinsic connection with bodies of water in New Zealand. ${ }^{197}$ The Tribunal also stressed the intrinsic connection of Māori to mātauranga Māori, taonga works and taonga species, ${ }^{198}$ so use of property rights through Carpenter Katyal and Riley's approach does not appear incompatible with the Tribunal's assessment of Māori interests in their traditional knowledge. But Carpenter, Katyal and Riley also rightly acknowledge that property rights to protect traditional knowledge will require a different conception from the traditional western basis of ownership, ${ }^{199}$ just as the Waitangi Tribunal in Wai 262 rejected the application of exclusive ownership as means of upholding kaitiaki interests. ${ }^{200}$ The right must be more relational, and obligation-based, justified by kaitikitanga.

The aim of discussing two possibilities of a sui generis legal framework for protection of traditional knowledge against misappropriation in a New Zealand context is to showcase that the current status quo would not fully comply with the recommended definition and objective, and the foundational customary law approaches. Thus, there will undoubtedly be a significant challenge in applying an aspirational definition, in that states such as New Zealand would have to move beyond the status quo in order to adhere to it. This shift away from the status quo may require a relatively drastic change or reconceptualisation of fundamental legal concepts such as property rights, to be effective. The Australian analysis reflects a similar challenge.

\section{Australia: an introduction}

The misappropriation of traditional knowledge is a significant concern of the indigenous Aboriginal and Torres Strait Islander Peoples. ${ }^{201}$ At the WIPO-IGC, Australia has stressed the importance of protecting traditional knowledge from misappropriation through the draft articles. ${ }^{202}$ Australia has also expressed concern with a "one size fits all" definition of misappropriation, given

197 Waitangi Tribunal The Stage 1 Report on the National Freshwater and Geothermal Resources Claim (Wai $2358,2012)$ at 62.

198 Ko Aotearoa Tēnei: Te Taumata Tuatahi, above n 1, at 22-23.

199 Carpenter, Katyal and Riley, above n 185, at 1026-1027.

200 Ko Aotearoa Tēnei: Te Taumata Tuatahi, above n 1, at 50.

201 Australia Bureau of Statistics "Estimates of Aboriginal and Torres Strait Islander Australians" (18 August 2018) <www.abs.gov.au/statistics/people>.

202 Intergovernmental Committee on Intellectual Property and Genetic Resources, Traditional Knowledge and Folklore The Protection Of Traditional Knowledge: Table of Written Comments on Revised Objectives and Principles WIPO/GRTKF/IC/11/5(B) (18 May 2007) at [annex, at 2]; and IGC, above n 9, at 70. 
the broad nature of traditional knowledge and the varied means through which misappropriation can occur. ${ }^{203}$ While Australia has acknowledged that the indigenous context of traditional knowledge should be recognised (such as the often communal character of the knowledge), ${ }^{204}$ it has also asserted that any new measures should be consistent with the existing IP regime. ${ }^{205}$ This approach arguably reflects the Australian domestic approach to protecting traditional knowledge against misappropriation, in that while it does afford some protection to indigenous traditional knowledge holders, it is constrained within the scope of the IP regime and contains little protection in the form of sui generis legislation or enforceable customary law. ${ }^{206}$

Before Australia's current domestic protections are traversed, it is worth noting that Australia provides significant support to the WIPO Voluntary Fund, which facilitates the participation of indigenous peoples in the WIPO-IGC. ${ }^{207}$ Given Australia's support of the WIPO-IGC, it appears to have expressed outward intent to support the protection of indigenous traditional knowledge from misappropriation. However, whether the state would extend this approach to implement a definition of misappropriation that would uphold customary law requires an assessment of Australia's current domestic legal framework of protection and its constraints.

\section{Australia: misappropriation of traditional knowledge and the copyright cases}

Indigenous traditional knowledge has been recognised in both statute and common law in Australia, albeit with a limited scope. The limited ambit of traditional knowledge is apparent in Western Australia $v$ Ward, where the High Court of Australia acknowledged that while indigenous traditional knowledge may be protected through common law and statute, ${ }^{208}$ it linked any possible rights to protection under the Native Title Act 1993 with the right to an interest in, or ownership of land. ${ }^{209}$ Consequently, following Ward, which was affirmed in Neowarra $v$ Western Australia,${ }^{210}$ the

203 IGC, above n 9, at 11.

204 At 19.

205 At 11.

206 Sentina, Mason and Janke, above n 96, at 5.

207 Intergovernmental Committee on Intellectual Property and Genetic Resources, Traditional Knowledge and Folklore Participation of Indigenous and Local Communities: Voluntary Fund WIPO/GRTKF/IC/39/3 (4 February 2019) at 1.

208 Western Australia v Ward [2002] HCA 28, (2002) 213 CLR 1 at 61.

209 At 64.

210 Neowarra $v$ Western Australia [2003] FCA 1402. 
likelihood of indigenous peoples utilising the Native Title Act to protect and enforce their rights over traditional knowledge is low. ${ }^{211}$

A string of copyright cases in the 1990s, mainly concerning the application of the Copyright Act 1968 (Cth), are the most cogent example of this limited protection against misappropriation within the Australian IP regime. Two cases are useful illustrations of this: Milpurrurru ${ }^{212}$ and Bulun Bulun. $^{213}$ The former concerned the unauthorised copying of the artwork of eight Aboriginal artists, which were produced in Vietnam and sold by an Australian-based textile company. ${ }^{214}$ The company argued that no copyright existed in the artworks, as they drew from pre-existing traditional designs, hence failing to meet the originality requirements under the Copyright Act. ${ }^{215}$ The Federal Court of Australia rejected this argument, holding that the works were original because the artists had imparted their own skill, labour, and effort to create a copyright work. ${ }^{216}$ A particularly important aspect of the judgment for the purposes of traditional knowledge was the award of damages. The defendant company was required to pay damages of $\$ 188,000$ and ordered to hand over the unsold carpets. ${ }^{217}$ In this case, the harm stemmed from the unauthorised copying of Aboriginal art of significant importance to the Aboriginal clan from which the artists descended. ${ }^{218}$ The paintings were (according to the artists) "our relationship with the land to be encoded ... an assertion of the rights that are held in the land", 219 hence the significant award of damages. One artist emphasised the customary law implications of unauthorised copying: $:^{220}$

The artist's right to reproduce designs and stories and to participate in ceremonies could be permanently removed. The artist could also be outcast from the community, required to financially recompense the community, or even speared.

While this case appears to indicate some recognition of a localised and holistic approach to dealing with misappropriation, it is constrained within the IP regime. If the artwork failed to satisfy the

211 Matthew Rimmer "Blame it on Rio: Biodiscovery, Native Title, and Traditional Knowledge" (2003) 7 Southern Cross University Law Review 1 at 22; and Western Australia v Ward, above n 208, at 64.

212 Milpurrurru, above n 43.

213 Bulun Bulun, above n 43.

214 Milpurrurru, above n 43, at 248.

215 At 256

216 At 248.

217 At 283

218 At 283 .

219 Janke, above n 1, at 30-31.

220 At 31 . 
originality requirements, or if it was in the public domain, or if it was a much older work (thus outside the copyright time period of protection), misappropriation may be able to occur legitimately within the intellectual property system. IP Australia recognised these constraints in recent reports, discussing the example of ancient Aboriginal rock art copied from a book about indigenous paintings onto clothing. ${ }^{221}$ While the book owner was able to seek redress through copyright, the indigenous custodians had no legal recourse for a remedy based on the misappropriation. ${ }^{222}$

The Bulun Bulun case also signified a tentative application of a localised, customary law approach. In that case, the artist and copyright owner commenced proceedings against a fabric company who had copied, without authorisation, one of his bark paintings (containing imagery sacred to the artist's clan group, the Ganalbingu people). ${ }^{223}$ The Federal Court of Australia found that as the painting contained sacred imagery, the artist had customary law obligations to his clan tantamount to a fiduciary duty. ${ }^{224}$ In effect, the artist had an obligation to refrain from doing anything that might harm the communal interests of the clan in the artwork, such as exploiting that artwork in a manner contrary to the clan's laws. ${ }^{225}$ Furthermore, the artist was compelled to take action against any infringement of the copyright by a third party. ${ }^{226}$ The Court suggested that had the artist not taken legal action against the company for copyright infringement, the clan would have been entitled under this fiduciary duty to bring an action against him to enforce the fiduciary obligation. ${ }^{227}$ This case therefore introduces the dynamic of a collective approach to remedying against misappropriation, enforced through equitable obligations.

The Copyright Act 1968 (Cth) (similarly to New Zealand) provides moral rights to performers and authors of literary, dramatic, musical or artistic works, ${ }^{228}$ which includes a right of attribution to the author or performer, ${ }^{229}$ rights against false attribution ${ }^{230}$ and a right of integrity of authorship or performership in respect of the work (which includes the right to not have the work subjected to

221 At 31 .

222 At 31.

223 Bulun Bulun, above n 43, at 246-247.

224 At 262 .

225 At 259

226 At 262

227 At 263-264.

228 Copyright Act 1968 (Cth), s 189.

229 Copyright Act, ss 193 and 195ABA.

230 Copyright Act, ss 195AC and 195AHA. 
derogatory treatment). ${ }^{231}$ However these moral rights have a limited application with regard to indigenous traditional knowledge, namely due to the fact that they can only apply to the individual authors or performers of the works. ${ }^{232}$ Another limitation of these moral rights, noted by Frankel in the New Zealand context (but the same can be applied to the Australian Copyright Act, given the similarity of the particular provision), is that the statutory provisions do not include the possibility of derogatory treatment by association with, or in a setting of, cultural inappropriateness. ${ }^{233}$ Hence while individual indigenous creators may be able to protect their works against misappropriation that is derogatory to them and their clan or people, indigenous clans or peoples themselves cannot use these rights to prevent misappropriation from occurring.

Ultimately, while there appears to be some protection for Aboriginal and Torres Strait Islander traditional knowledge under Australian copyright law, and at least a recognition of Aboriginal customary law, there is very little protection which could be classed as either sui generis legislation or customary-law based. ${ }^{234}$ The cases of Milpurrurru and Bulun Bulun indicate a willingness by the judiciary to acknowledge customary law, but only when it is consistent with the current IP regime. Even the somewhat holistic, communal approach of fiduciary obligations introduced in Bulun Bulun are limited both by the fact that the artist already had clear rights under the IP regime as the copyright owner, and by the explicit assertion in the earlier case of Yulumbul v Reserve Bank of Australia, where the Federal Court of Australia found that Australia's copyright law did not provide adequate recognition of Aboriginal community claims to regulate the reproduction of works that are essentially communal in origin. ${ }^{235}$ In her assessment of the Bulun Bulun case, Bowrey highlights this tension by depicting it as a situation whereby the Court's apparent openness to indigenous customary law and collective ownership was moderated by its obligation to preserve the integrity of "mainstream" copyright law. ${ }^{236}$ This ultimately made it difficult to fully accommodate indigenous communal ownership. Bowrey contrasts this with the willingness of the judicial system to stretch the same

231 Copyright Act, ss 195AI and 195ALA.

232 Sentina, Mason and Janke, above n 96, at 5 and 9-10

233 Susy Frankel "Towards a Sound New Zealand Intellectual Property Law" (2001) 32 VUWLR 47 at 70 . For examples of derogatory treatment by association with, or in a setting of, cultural inappropriateness in the New Zealand context, see Ko Aotearoa Tēnei: Te Taumata Tuatahi, above n 1, at 48-49.

234 Christoph B Graber "Aboriginal Self-Determination vs the Propertisation of Traditional Culture: The Case of the Sacred Wanjina Sites" (2009) 13(2) AILR 18 at 22.

235 Yulumbul v Reserve Bank of Australia (1991) IPR 481 (FCA).

236 Bowrey, above n 97, at 81 . 
constraining concepts of copyright to accommodate the collective authority and ownership of corporations. $^{237}$ As aptly summarised by Bowrey: ${ }^{238}$

... why is it that all the concepts and categories that touch on the indigenous involve impossible demands, and all those that relate to reinvigorating the rights to accommodate mainstream culture and economy show up the law as flexible, malleable and constantly able to be legally renewed? There seems to be something about the way we understand custom and indigenous difference that produces an impasse.

\section{Australia: misappropriation of traditional knowledge and other legislation}

The same issues arise in both patent and trade mark law. The Patents Act 1990 (Cth) sets out similar requirements for patentability as its New Zealand counterpart, including novelty, prior art and inventive step. ${ }^{239}$ However unlike in New Zealand, the Australian legislation does not provide for an indigenous patents advisory committee, and does not make any particular reference to indigenous traditional knowledge. Consequently, any indigenous individual or group seeking to oppose a patent application which uses or misappropriates traditional knowledge would have to do so by proving that the patentability requirements under the Act are not satisfied.

Similarly, while there are some protections within the Trade Marks Act 1995 (Cth), they appear to be very rarely used. ${ }^{240}$ Under this legislation, third parties may oppose the registration of a trade mark if it is scandalous or contrary to law. ${ }^{241}$ Indigenous peoples may be able to successfully oppose the registration of a trade mark if they can prove that it is sufficiently culturally offensive to be scandalous under the legislation. Therefore outside of registering their own symbols as trade marks (which could give rise to issues satisfying the statutory requirements), indigenous peoples have little recourse under Australian trade mark legislation to protect their symbols.

Consequently, Australia's current legal framework cannot be considered to effectively apply the three recommended customary law approaches discussed above. Firstly, with regard to a localised approach, there is little room within Australia's current legal framework to provide Aboriginal and Torres Strait Islander peoples with the discretion to apply their own local customary law to the issue of traditional knowledge misappropriation. The Aboriginal Heritage Amendment Act 2016 (Vic) does provide Aboriginal peoples in the State of Victoria some autonomy to protect certain aspects of their

237 At 81.

238 At 82 (emphasis omitted).

239 Patents Act 1990 (Cth), s 7.

240 Sentina, Mason and Janke, above n 96, at 19-21.

241 Trade Marks Act 1995 (Cth), ss 42 and 57. 
traditional knowledge. However this is within the limitations of the statute and the heritage agreements. $^{242}$

Furthermore, while the Biological Resources Act 2006 (NT) seeks to rectify issues of misappropriation over traditional knowledge of biological resources within the Northern Territory through requiring access and benefit-sharing agreements when biological resources are used which have indigenous knowledge associated with them, it does not apply the local customary law, and has limited application. ${ }^{243}$ In the Australian context, this localised approach is critical because of the varied range of indigenous clans and groups across Australia which may have differing views regarding how traditional knowledge can be protected against misappropriation through customary law. This point was stressed at the 16th Session of the WIPO-IGC draft articles negotiations, whereby the Australian representative to the WIPO Indigenous Panel on Free, Prior and Informed Consent discussed the importance of having primacy of local indigenous perspectives in forming the draft articles. $^{244}$ Effectively, the creation of a broad, "intercultural" definition would be of little use if it was not refined and clarified in relation to its legitimacy at a local indigenous level. ${ }^{245}$

Secondly, there are also very few means for applying a communal approach in Australia's current legal framework. Two limited examples of where this may occur are the case of Bulun Bulun, which set out limited fiduciary duties based on customary law obligations, and the Aboriginal Heritage Amendment Act 2016 which arguably allows for some communal rights for indigenous through heritage agreements. However outside of this, there are few opportunities for recognition and protection of communal rights. In particular, it would be difficult for indigenous groups to protect their traditional knowledge if it either exists in the public domain, or if it is communally held and created, and therefore unlike Bulun Bulun, where there was an individual creator. The Copyright Act 1968 and the case of Yulumbul both demonstrate that Australian law does not protect copyright works that are communal in origin.

Finally, the current legal framework also lacks a holistic approach. Outside of the two cases of Milpurrurru and Bulun Bulun, which incorporated some facets of customary law, Australia lacks any

242 Aboriginal Heritage Amendment Act 2016 (Vic), ss 5, 79G and 79B(1). Under the Act, indigenous owners may make heritage agreements that set out how their traditional knowledge is used, but this does not include Aboriginal heritage that is effectively in the public domain, as any "widely known" Aboriginal heritage cannot be registered.

243 Biological Resources Act 2011 (NT), s 29.

244 Intergovernmental Committee on Intellectual Property and Genetic Resources, Traditional Knowledge and Folklore WIPO Indigenous Panel on Free, Prior and Informed Consent: Experiences in the Fields of Genetic Resources, Traditional Knowledge and Traditional Cultural Expressions: Experiences From Australia WIPO/GRTKF/IC/16/INF/5(F) (3 May 2010) at 4.

245 At 4. 
explicit sui generis legislation which would allow Aboriginal and Torres Strait Islander peoples the ability to apply their own worldview to issues of misappropriation.

\section{Australia: a sui generis regime}

If Australia was to properly implement the recommended definition in a manner that did uphold all three customary law approaches, one possible means of doing so would be to implement a comprehensive sui generis legislative framework. ${ }^{246}$ In their report on Australian indigenous cultural and intellectual property rights, Janke and Frankel put forward suggestions for sui generis legislation that had the potential to be consistent with, and uphold, indigenous customary law. ${ }^{247}$ They note that for sui generis legislation to effectively protect indigenous traditional knowledge against misappropriation, it must be flexible enough to include factors such as intergenerational rights, or even rights in perpetuity, so as to protect knowledge being passed down generation to generation. ${ }^{248}$

Janke and Frankel also assert that any effective sui generis legislation framework would need to recognise communal ownership rights. ${ }^{249}$ They identify that a critical limitation of the current IP regime is that it focuses on individual notions of ownership, rather than collective or communal ownership. Thus sui generis legislation that would be consistent with indigenous customary law would have to recognise that traditional knowledge is often collectively owned, socially based, with continuous evolution and different generations having ownership rights. ${ }^{250}$ Finally, there ought to be a holistic approach to sui generis legislation, so that it provides indigenous peoples with the autonomy to develop (within their various local power structures) mechanisms to strengthen their culture. ${ }^{251}$ Perhaps the most critical aspect of any sui generis legislation implemented in Australia, would be its recognition of customary law itself. Although, as discussed above, Australian case law seems to indicate a willingness of the judiciary to at least acknowledge and partially consider indigenous customary law, the legislation does not arguably even go that far. Thus, as noted by Kuruk, effective sui generis legislation cannot mirror the current legislative incorporation or inclusion of indigenous

246 For a parallel argument supporting this assertion, based on analysis of traditional knowledge in the Pacific Islands Region see Miranda Forsyth "How Can Traditional Knowledge Best Be Regulated? Comparing a Proprietary Rights Approach with a Regulatory Toolbox Approach" (2013) 25 The Contemporary Pacific 1 at 7; and Miranda Forsyth "Do You Want it Gift Wrapped?: Protecting Traditional Knowledge in the Pacific Island Countries" in Peter Drahos and Susy Frankel (eds) Indigenous Peoples' Innovation: Intellectual Property Pathways to Development (ANU Press, Canberra, 2012) 189.

247 Terri Janke and Michael Frankel Our Culture: Our Future - Report on Australian Indigenous Cultural and Intellectual Property Rights (Australian Institute of Aboriginal and Torres Strait Islander Studies and the Aboriginal and Torres Strait Islander Commission, 1998).

248 At 8 .

249 At $183-184$.

250 At 272.

251 At 272. 
customary law; namely, it cannot be erratic, uncoordinated and incomplete. ${ }^{252}$ Instead, it must be enforceable within the legislation. This is not to suggest that customary law should be whittled down to a rigid set of rules, as this would contradict its holistic and localised nature. It should instead be referenced and enforceable, but in a manner which empowers the aggrieved indigenous group to apply their own customary law to the particular issue of misappropriation. ${ }^{253}$

\section{Critique of Definition}

Given the analysis above, perhaps the most substantial critique of this recommended definition is that it is more aspirational than practical. States may be reluctant to apply indigenous customary law within a definition of misappropriation, leading them to either reject the definition, ${ }^{254}$ or "forum shift" to an institution where they have fewer obligations to indigenous peoples. ${ }^{255}$ This leads to either the proposed definition being undermined, ${ }^{256}$ or ignored, ${ }^{257}$ as Drahos asserts: "forum shifting means that some negotiations are never really over". ${ }^{258}$ Kuruk suggests that the sometimes informal and flexible nature of indigenous customary law may make it difficult for states to apply a localised or holistic approach. ${ }^{259}$ Furthermore, states may be confronted with the definitional question regarding whose practices ought to be taken into account, where there are significant differences in customary practices among sections of a tribe or a clan. ${ }^{260}$ To take a single example from the WIPO-IGC process, the Delegation representing the United States of America opposed the inclusion of certain proposed

252 Paul Kuruk "The Role of Customary Law under Sui Generis Frameworks of Intellectual Property Rights in Traditional and Indigenous Knowledge" (2007) 17 Ind Int'l \& Comp L Rev 67 at 101.

253 At 102

254 Intergovernmental Committee on Intellectual Property and Genetic Resources, Traditional Knowledge and Folklore Draft Report on the Twenty-First Session of the Intergovernmental Committee on Intellectual Property and Genetic Resources, Traditional Knowledge and Folklore WIPO/GRTKF/IC/21/7/PROV.2 (16 July 2012) at [563]; and Charles Lawson, Edwin Bikundo and Kieran Tranter "The Perils of Parliamentarism: The World Intellectual Property Organization and Indigenous Peoples" (2019) 39 OJLS 285 at 286.

255 Laurence R Helfer "Regime Shifting: The TRIPS Agreement and New Dynamics of International Intellectual Property Lawmaking" (2004) 29 Yale J Int'l L 1.

256 Susan K Sell "TRIPS Was Never Enough: Vertical Forum Shifting, FTAS, ACTA, and TTP" (2011) 18 J Intell Prop L 448.

257 Chidi Oguamanam "Ramifications of WIPO IGC for IP and Development" in Daniel Robinson, Ahmed Abdel-Latif and Pedro Roffe (eds) Protecting Traditional Knowledge: The WIPO Intergovernmental Committee on Intellectual Property and Genetic Resources, Traditional Knowledge and Folklore (Routledge, Abingdon (UK), 2017) 339 at 341.

258 Peter Drahos "Four Lessons for Developing Countries from the Trade Negotiations over Access to Medicines" (2007) 28 Liverpool LR 11 at 35.

259 Kuruk, above n 252, at 113.

260 At 115. 
objectives in the 8th Session within the draft articles. ${ }^{261}$ The Delegation opposed the phrase "empowering indigenous communities to exercise rights and authority" over their traditional knowledge in one of the objectives. ${ }^{262}$ However this phrase, as noted by Solomon, was critical because it encouraged states to empower indigenous peoples to utilise their own customary law approaches to issues of misappropriation, signalling a progressive shift away from the IP regime and towards a sui generis model. ${ }^{263}$ Given the phrase, and the objective as a whole, was removed, it appears that states may not yet be willing to confer this level of self-determination upon indigenous peoples.

This opposition, as a result of possible reluctance to allow for indigenous self-determination, is also exemplified in New Zealand. The failure of the Crown to implement all three patent law recommendations forecasts potential issues with how a definition of misappropriation which incorporates the customary law approaches might be applied practically. For example under s 15(3) of the Patents Act 2013, the Patents Māori Advisory Committee only has a limited advisory role, and its recommendations do not have to be followed. ${ }^{264}$ Conversely, in Wai 262, the Tribunal recommended that the Advisory Committee should ensure that mātauranga Māori is treated as a key factor relevant to patentability criteria in the intellectual property system. ${ }^{265}$ This would be achieved by allowing the Committee to advise the Commissioner on different areas of patentability, including novelty and inventive step, as well as what is contrary to morality and ordre public. ${ }^{266}$

There is also no compulsory requirement for patent applicants to disclose whether any mātauranga Māori or taonga species have been used in the research/invention process, and no consequences for failure to disclose. This is the subject of a discussion paper released by the Ministry of Business, Innovation and Employment, following the recommendations of the Waitangi Tribunal in Wai 262. ${ }^{267}$ Importantly, the paper does recognise that while the Māori Patents Advisory Committee can assist in

261 Intergovernmental Committee on Intellectual Property and Genetic Resources, Traditional Knowledge and Folklore Draft Report on the Ninth Session of the Intergovernmental Committee on Intellectual Property and Genetic Resources, Traditional Knowledge and Folklore WIPO/GRTKF/IC/9/14/Prov.2 (5 November 2006) at [113].

262 At [113]

263 Solomon, above n 5, at 223-225.

264 Jessica C Lai "Māori Traditional Knowledge and New Zealand Patent Law: The 2013 and the Dawn of a New Era" (2014) 17 J World Intellect Prop 34 at 39.

265 Ko Aotearoa Tēnei: Te Taumata Tuatahi, above n 1, at 95-97.

266 At $95-97$.

267 Ministry of Business, Innovation and Employment Discussion Paper: disclosure of origin of genetic resources and traditional knowledge in the patents regime (September 2018). See generally Brooke Marriner "Disclosure of Origin in the Patents Regime: A Call to Shift Towards Meaningful Engagement on Māori Terms" (2020) 51 VUWLR 673, also in this special issue. 
preventing registration of inventions for which commercial exploitation could be offensive to Māori, there is a possibility of misappropriation still being missed in the registration system. ${ }^{268}$ The inclusion of a disclosure requirement would be an improvement to the system, as its current constraints are illustrated in the discussion of mānuka above.

The relatively limited recognition of mātauranga Māori in the Patents Act consequently signifies a reluctance by the state to enact serious adjustment to the IP regime to properly uphold tikanga. It is worth reiterating that in Wai 262, the Tribunal did not endorse rejecting the entire intellectual property system. ${ }^{269}$ Instead, its recommendations, although likely to have an impact on the patent application process, provided a useful framework which supported an approach based on tikanga within the confines of the intellectual property system. The unwillingness of the state to make any upheavals to the system itself may therefore hinder the practical application of the suggested definition of misappropriation.

In the Australian context, the same hindrance is a theme underlying the analysis of Australia's current legal framework: the limited application of indigenous customary law within the constraints of the IP regime. A critical challenge for the application of any customary law-based definition of misappropriation is how it may conflict with current laws governing intellectual property in the state.

This is not to suggest that the Australian Government has failed to recognise challenges between intellectual property and customary law. In its report on the interaction of Western Australian law with Aboriginal law and culture, ${ }^{270}$ the Law Reform Commission of Western Australia noted the possible inappropriateness of solely utilising the common law to protect indigenous traditional knowledge. ${ }^{271}$ Despite this, Stoianoff and Roy posit that Australia has expressed significant reluctance with a definition which places specific obligations upon the domestic law of states, preferring a more general definition. ${ }^{272}$ This is evidenced through statements made during the 19th Session, where the Delegation of Australia suggested that the WIPO-IGC "recall that it was seeking to draft the text of an international instrument, not a domestic law".273

268 At vi.

269 Ko Aotearoa Tēnei: Te Taumata Tuatahi, above n 1, at 50-51.

270 The Law Reform Commission of Western Australia Aboriginal Customary Laws the Interaction of Western Australian Law with Aboriginal Law and Culture (Project 94 Final Report, 2006).

271 At 265 .

272 Natalie Stoianoff and Alapana Roy "Indigenous Knowledge and Culture in Australia: The Case for Sui Generis Legislation" (2016) 41 Mon LR 745 at 747.

273 Intergovernmental Committee on Intellectual Property and Genetic Resources, Traditional Knowledge and Folklore Report of the Nineteenth Session of the Intergovernmental Committee on Intellectual Property and Genetic Resources, Traditional Knowledge and Folklore WIPO/GRTKF/IC/19/12 (23 February 2013) at [39]. 
Furthermore, at the 16th Session, Australia (in conjunction with New Zealand, Canada, Norway and the United States of America) submitted proposed objectives for misappropriation specifically in the field of genetic resources. ${ }^{274}$ These are illustrative of a position taken by these states whereby the underlying principles within the IP regime are prioritised over principles of customary law. The states were cognisant of the need to ensure inventors using traditional knowledge associated with genetic resources comply with access, use and benefit-sharing conditions within each particular state or region. ${ }^{275}$ However, the majority of the objectives put forward by the states relate to standard patent requirements and objectives, such as the requirement of novelty and inventive step, and maintaining the purpose behind patents as promoting innovation. ${ }^{276}$ It is also specifically stressed that sovereign states must have authority over determining access to genetic resources in their jurisdiction. ${ }^{277}$

This approach fails to recognise the "gaps" in traditional knowledge protection against misappropriation through the intellectual property system, as discussed by the WIPO-IGC in its gap analysis, ${ }^{278}$ and in early documents published around the time of the formation of the WIPO-IGC. ${ }^{279}$ The WIPO-IGC recognised that customary law was an important consideration in developing a definition, and that a comprehensive approach to protection of traditional knowledge against misappropriation would recognise the limits of using exclusive property rights through the IP system as an appropriate tool for protection. ${ }^{280}$ Furthermore, a broader "umbrella" definition drafted to allow for localised and holistic protection against misappropriation was recommended, given that both traditional knowledge and customary law are dynamic and variable, and more likely to be shaped by local, cultural factors than intellectual property within the IP regime. ${ }^{281}$ There is therefore a conflict between Australia's approach, which emphasises protection within the IP regime, and the WIPO-IGC's acknowledgement that in order to be effective and consistent within customary law, a definition of

274 Intergovernmental Committee on Intellectual Property and Genetic Resources, Traditional Knowledge and Folklore Submission by Australia, Canada, New Zealand, Norway and the United States of America WIPO/GRTKF/IC/16/7 (6 May 2010).

275 At 2 .

276 At $2-3$.

277 At $2-3$

278 IGC, above n 6, at 23-25.

279 IGC, above n 11, at 5-7; Intergovernmental Committee on Intellectual Property and Genetic Resources, Traditional Knowledge and Folklore Revised Version of Traditional Knowledge: Policy and Legal Options WIPO/GRTKF/IC/6/4/Rev (19 February 2004) at 7-8; and Intergovernmental Committee on Intellectual Property and Genetic Resources, Traditional Knowledge and Folklore Composite Study on the Protection of Traditional Knowledge WIPO/GRTKF/IC/5/8 (28 April 2004) at 42-43.

280 IGC Revised Version of Traditional Knowledge, above n 279, at 7.

281 At $20-21$. 
misappropriation may have to move beyond the boundaries of the IP regime. This perhaps signals potential difficulties with Australia's application of the recommended definition at a domestic level.

When developing a definition of misappropriation within its draft articles, the WIPO-IGC is faced with a tension that is not easily resolved. This is between the IP regime which is based upon concepts of property which strongly favour individual ownership, and indigenous customary law which arguably rejects the notion of ownership and places greater emphasis on collective rights, obligations and guardianship. This tension is augmented by the minimal likelihood that states in applying this definition, will treat indigenous customary law in a manner equal to their own common law.

A compelling counter to the reluctance of states is that indigenous peoples do have rights over their traditional knowledge, and rights to maintain their customary laws. ${ }^{282}$ These are present in UNDRIP, which recognises the right of indigenous peoples to maintain, control, protect and develop their intellectual property over their traditional knowledge and traditional cultural expressions. ${ }^{283} \mathrm{As}$ noted by the previous Special Rapporteur on the rights of indigenous peoples, the art 31 right over intellectual property is supplemented by, and works in tandem with, the art 3 right of indigenous peoples to exercise self-determination and (under art 4) in exercising that right to self-determination, the right to autonomy in matters relating to their own local and internal affairs. ${ }^{284}$ Thus under UNDRIP, indigenous peoples are entitled to exercise their own customary law over misappropriation of traditional knowledge. ${ }^{285}$ This is particularly pertinent given that UNDRIP is explicitly mentioned and acknowledged in the preamble of the current WIPO-IGC draft articles on traditional knowledge. ${ }^{286}$

These rights are also present in the $\mathrm{CBD},{ }^{287}$ as well as garnering a growing recognition in domestic sui generis legislation. ${ }^{288}$ Given their existence, states therefore should aspire to recognise

282 Intergovernmental Committee on Intellectual Property and Genetic Resources, Traditional Knowledge and Folklore Report of Indigenous Expert Workshop on Intellectual Property and Genetic Resources, Traditional Knowledge and Traditional Cultural Expressions WIPO/GRTKF/IC/28/INF/9 (8 May 2014) at [annex, at 1].

283 Article 31

284 Intergovernmental Committee on Intellectual Property and Genetic Resources, Traditional Knowledge and Folklore Technical Review of Key Intellectual Property-Related Issues of the WIPO Draft Instruments on Genetic Resources, Traditional Knowledge and Traditional Cultural Expressions By Professor James Anaya WIPO/GRTKF/IC/31/INF/9 (13 May 2016) at 1-2.

285 Graber, above n 234, at 27.

286 IGC, above n 8 , at 2 .

287 CBD, above n 57, art 8(j).

288 Ruth Okediji Traditional Knowledge and the Public Domain (Centre for International Governance Innovation, CIGI Papers No 176, June 2018) at 8-9. See also Law No 27811 - Law Introducing a Protection Regime for the Collective Knowledge of Indigenous Peoples Derived from Biological Resources 2002 (Peru); Forsyth, above n 246; Secretariat of the Pacific Community, Pacific Islands Forum Secretariat and UNESCO 
and uphold them by utilising a definition of misappropriation which applies an indigenous customary law approach. There may be some impracticalities, but the Wai 262 report provides an example of how states can employ this definition without wholly rejecting the intellectual property system. A submission to WIPO and the United Nations by a number of indigenous organisations concerning the language in the Nagoya Protocol illustrates the danger of the WIPO-IGC being too cautious. ${ }^{289}$ The central purpose of the submission was to highlight the substantive and procedural injustices caused to indigenous peoples by the wording of the protocol, which the organisations considered too ambiguous and tentative to actually be effective in protecting indigenous peoples' rights. ${ }^{290}$

\section{CONCLUSION}

Ascertaining a definition of misappropriation which balances the importance of upholding indigenous customary law, while staying within the confines of the intellectual property system is a singularly difficult issue in international property law. However given the effects of misappropriation on indigenous peoples, it is pivotal that organisations like the WIPO-IGC reach a solution. This article has argued that in order to reach an effective solution which will provide indigenous peoples with the protection they are entitled to as self-determined units within states, the WIPO-IGC must properly consider and take into account indigenous customary law when developing a definition of misappropriation. Reasons why indigenous customary law must be taken into account in this definition have been presented in this article. Ultimately, they stem from the inherent tension between the IP regime and indigenous customary law. Hence the collective, obligation-based, relational and stewardship-oriented application of indigenous customary law is often either constrained by, or fits uncomfortably with, aspects of the western IP regime. ${ }^{291}$

Upon analysis of the current state of the intellectual property legal framework in New Zealand and Australia, the recommended definition provided in this article (which seeks to uphold indigenous customary law), would require significant legal change, or even a partial re-framing of the foundational perspectives underlying intellectual property law, to be properly implemented. This conclusion is strengthened by the fact that a hypothetical sui generis regime in both states which does go some way to upholding customary law and the three approaches advanced in this article, contrasts starkly with the status quo. It is not apparent that either state is willing to undergo such formative change. While Australia has recently released a broad paper on issues for protection and management

Pacific Regional Office, above n 55, arts 4-7; Bill for the Protection Of Traditional Knowledge and Expressions of Culture 2018 (Vanuatu), cl 4; and Tāoga Niue Act 2012 (Niue), ss 26-27.

289 WIPO Expert Mechanism on the Rights of Indigenous Peoples Nagoya Protocol on Access and Benefit Sharing: Substantive and Procedural Injustices relating to Indigenous Peoples' Human Rights (15 July 2011). 290 At 1.

291 Carpenter, Katyal and Riley, above n 185, at 1026-1027. 
in indigenous knowledge, ${ }^{292}$ and the New Zealand Government has released its official response to Wai $262,{ }^{293}$ but application of the recommended definition will still require not only significant domestic change, but also international acceptance and amendment of the current WIPO-IGC definition, which states such as New Zealand and Australia appear reluctant to do. ${ }^{294}$

There is ample literature warning of the dangers of adopting too aspirational a definition of misappropriation: forum-shifting, the inability of states to apply it, inconsistency with the current regime and the stifling of innovation are commonly cited. ${ }^{295}$ These factors, combined with the difficulties of domestic application analysed in this article, suggest that adopting a more moderate definition consistent with the IP regime status quo would be a more pragmatic decision by the WIPOIGC. However the status quo has not sufficiently protected traditional knowledge from misappropriation, nor has it fully upheld indigenous self-determination as espoused in UNDRIP. ${ }^{296}$ The most effective means, as set out in this article, of achieving those twin goals is to better apply and uphold indigenous customary law. The risks inherent in an aspirational definition of misappropriation that does so are outweighed by the potential of achieving those twin goals by normalising and encouraging indigenous customary law as the foundational basis for protection of traditional knowledge against misappropriation. This potential will admittedly take significant effort by states and indigenous peoples to be realised. Nevertheless, it is the position of this article that it is the only appropriate way for, in the words of Te Kooti, the [indigenous customary] "Law" to correct the Law.

Ko te waka hei hoehoenga mo koutou i muri i ahau, ko te Ture, mā te ture anō te Ture e āki.

The canoe for you to paddle after me is the Law, for only the Law can correct the Law.

292 Janke, above n 1.

293 Te Puni Kōkiri, above n 124.

294 See for example IGC, above n 274, at 2-3 (discussed in Part III(C) "Critique of definition" above).

295 See IGC, above n 274, at 2-3; Sean A Pager "Traditional Knowledge Rights and Wrongs" (2016) 20 Virginia Journal of Law and Technology 82; Jim Chen "There's No Such Thing as Biopiracy ... and it's a Good Thing Too" (2006) 37 McGeorge Law Review 1; and Justin Hughes "Traditional Knowledge, Cultural Expression and the Siren's Call of Property" (2012) 49 San Diego L Rev 1215. For a broader critique of the idea of cultural property more generally see Naomi Mezey "The Paradoxes of Cultural Property" (2007) 107 Colum L Rev 2004.

296 Articles 3-4. 
